\title{
Role of ozone in SOA formation from alkane photooxidation
}

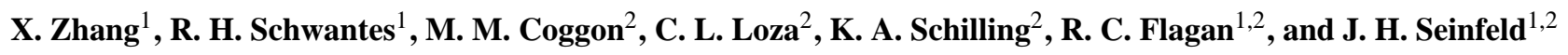 \\ ${ }^{1}$ Division of Engineering and Applied Science, California Institute of Technology, Pasadena, CA, USA \\ ${ }^{2}$ Division of Chemistry and Chemical Engineering, California Institute of Technology, Pasadena, CA, USA
}

Correspondence to: J. H. Seinfeld (seinfeld@ caltech.edu)

Received: 15 August 2013 - Published in Atmos. Chem. Phys. Discuss.: 24 September 2013

Revised: 2 January 2014 - Accepted: 9 January 2014 - Published: 14 February 2014

\begin{abstract}
Long-chain alkanes, which can be categorized as intermediate volatility organic compounds, are an important source of secondary organic aerosol (SOA). Mechanisms for the gas-phase $\mathrm{OH}$-initiated oxidation of long-chain alkanes have been well documented; particle-phase chemistry, however, has received less attention. The $\delta$-hydroxycarbonyl, which is generated from the isomerization of alkoxy radicals, can undergo heterogeneous cyclization and dehydration to form substituted dihydrofuran. Due to the presence of $\mathrm{C}=\mathrm{C}$ bonds, the substituted dihydrofuran is predicted to be highly reactive with $\mathrm{OH}$, and even more so with $\mathrm{O}_{3}$ and $\mathrm{NO}_{3}$, thereby opening a reaction pathway that is not usually accessible to alkanes. This work focuses on the role of substituted dihydrofuran formation and its subsequent reaction with $\mathrm{OH}$, and more importantly ozone, in SOA formation from the photooxidation of long-chain alkanes. Experiments were carried out in the Caltech Environmental Chamber using dodecane as a representative alkane to investigate the difference in aerosol composition generated from "OH-oxidationdominating" vs. "ozonolysis-dominating" environments. A detailed mechanism incorporating the specific gas-phase photochemistry, together with the heterogeneous formation of substituted dihydrofuran and its subsequent gas-phase $\mathrm{OH} / \mathrm{O}_{3}$ oxidation, is used to evaluate the importance of this reaction channel in dodecane SOA formation. We conclude that (1) the formation of $\delta$-hydroxycarbonyl and its subsequent heterogeneous conversion to substituted dihydrofuran is significant in the presence of $\mathrm{NO}_{\mathrm{x}}$; (2) the ozonolysis of substituted dihydrofuran dominates over the $\mathrm{OH}$-initiated oxidation under conditions prevalent in urban and rural air; and (3) a spectrum of highly oxygenated products with carboxylic acid, ester, and ether functional groups are produced from the substituted dihydrofuran chemistry, thereby affecting the average oxidation state of the SOA.
\end{abstract}

\section{Introduction}

Alkanes are important constituents of gasoline and vehicle emissions (Hoekman, 1992; Zielinska et al., 1996; Kirchstetter et al., 1999; Gentner et al., 2012; Jathar et al., 2013), accounting for $\sim 50 \%$ of volatile organic compounds (VOCs) in the urban atmosphere (Fraser et al., 1997; Schauer et al., 1999 and 2002). The unresolved complex mixture (UCM) of organics, which is potentially a significant source of secondary organic aerosol (SOA) formation in the atmosphere, has recently been shown to comprise many long-chain alkanes (Isaacman et al., 2012), which are expected to contribute to SOA formation (Robinson et al., 2007).

Laboratory chamber investigations of SOA formation from long-chain alkanes (Lim and Ziemann, 2005, 2009a, b, c; Presto et al., 2009, 2010; Miracolo et al., 2010, 2011; Craven et al., 2012; Lambe et al., 2012; Tkacik et al., 2012; Yee et al., 2012; Loza et al., 2013) provide a framework for understanding chemical mechanisms and determination of SOA yields (Jordan et al., 2008; Aumont et al., 2012 and 2013; Cappa et al., 2013; Zhang and Seinfeld, 2013). Particle-phase products from $\mathrm{OH}$ oxidation of alkanes contain a number of functional groups: organonitrate $\left(-\mathrm{ONO}_{2}\right)$, hydroxyl $(-\mathrm{OH})$, carbonyl $(-\mathrm{C}=\mathrm{O})$, ester $(-\mathrm{C}(\mathrm{O}) \mathrm{O}-)$, and hydroxyperoxide $(-\mathrm{OOH})$. Ambient measurements of organic aerosol composition have shown, in addition, that the carboxylic acid functional group $(-\mathrm{C}(\mathrm{O}) \mathrm{OH})$ is closely associated with products from fossil fuel combustion sources (Liu et al., 2011; Russell et al., 2011), of which alkanes are a principal component.

Atmospheric alkanes react in daytime exclusively with $\mathrm{OH}$, producing an array of peroxy radicals $\left(\mathrm{RO}_{2}\right)$. In the presence of sufficient $\mathrm{NO}$, the alkoxy radical (RO) is the key product of the subsequent $\mathrm{RO}_{2}$ reaction with $\mathrm{NO}$. $\mathrm{RONO}_{2}$ 
is also produced, with a branching ratio of $0.1-0.3$ (Arey et al., 2001). For alkanes with carbon number $\geq 5$, the $1,5-\mathrm{H}$ shift isomerization is the dominant reaction pathway for RO, producing a $\delta$-hydroxycarbonyl, the primary fate of which is reaction with $\mathrm{OH}$ (Jenkin et al., 2003; Saunders et al., 2003; Bloss et al., 2005), with a lifetime of $\sim 11.5 \mathrm{~h}$ at room temperature and a typical ambient $\mathrm{OH}$ concentration of $1 \times 10^{6}$ molecules $\mathrm{cm}^{-3}$. One particular $\delta$-hydroxycarbonyl, 5-hydroxy-2-pentanone, was found to cyclize to form the cyclic hemiacetal. The cyclic hemiacetal can subsequently lose water to form 4,5-dihydro-2-methylfuran, with an overall lifetime as short as $\sim 1.1 \mathrm{~h}$ at $298 \mathrm{~K}$ (Cavalli et al., 2000; Martin et al., 2002). The presence of water vapor can, in principle, serve to convert the 4,5-dihydro-2-methylfuran back to 5-hydroxy-2-pentanone, leading to an equilibrium between these two species within several hours (Martin et al., 2002; Baker et al., 2005; Holt et al., 2005; Reisen et al., 2005):

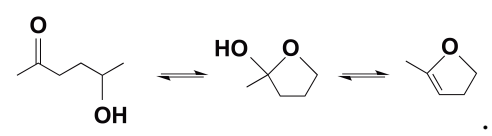

This conversion to 4,5-dihydro-2-methylfuran is not unique to 5-hydroxy-2-pentanone and also occurs for other $\mathrm{C}_{5}-\mathrm{C}_{17} \delta$ hydroxycarbonyls (Lim and Ziemann, 2005, 2009a, b, c) at a rate that increases with the length of the carbon chain (Holt et al., 2005; Ziemann and Atkinson, 2012). The substituted dihydrofuran is highly reactive towards $\mathrm{OH}, \mathrm{O}_{3}$, and $\mathrm{NO}_{3}$ in the gas phase, owing to the presence of a $\mathrm{C}=\mathrm{C}$ double bond. For typical ambient concentrations of $\mathrm{OH}, \mathrm{O}_{3}$, and $\mathrm{NO}_{3}$, i.e., $2 \times 10^{6}$ molecules $\mathrm{cm}^{-3}$ ( $12 \mathrm{~h}$ average), $30 \mathrm{ppb}$ ( $24 \mathrm{~h}$ average), and $5 \times 10^{8}$ molecules $\mathrm{cm}^{-3}$ (12 h average), respectively, the lifetimes of the substituted dihydrofuran with respect to reactions with these oxidants in the gas phase are $1.3 \mathrm{~h}, 7 \mathrm{~min}$, and $24 \mathrm{~s}$, respectively (Martin et al., 2002; Ziemann and Atkinson, 2012). Based on these estimates, ozonolysis of substituted dihydrofurans may dominate $\mathrm{OH}$ oxidation during daytime in the urban atmosphere.

SOA formation from long-chain alkanes involves multiple generations of $\mathrm{OH}$ oxidation that include functionalization (O-atom addition in forms of a variety of moieties) and fragmentation of the parent carbon backbone. These two routes can eventually lead to highly oxygenated fragments that partition into the particle phase. Two recent modeling studies of $\mathrm{C}_{12}$ alkanes suggest that particle-phase chemistry might play a potentially important role in the chemical composition of alkane SOA; this is inferred from the fact that simulations driven solely by gas-phase chemistry can successfully reproduce the chamber-measured SOA yield, but these fail to replicate the observed particulate $\mathrm{O}: \mathrm{C}$ and $\mathrm{H}: \mathrm{C}$ ratios in the absence of a particle-phase chemistry channel (Cappa et al., 2013; Zhang and Seinfeld, 2013). The extent to which particle-phase chemistry is important in alkane SOA formation has not been clearly established.

We address here the heterogeneous formation of substituted dihydrofurans and their subsequent gas-phase reaction with ozone in SOA formation from alkanes. We present the results of a series of chamber dodecane photooxidation experiments under two reaction regimes, i.e., "OH-dominant", in which over $70 \%$ of substituted dihydrofurans are oxidized by $\mathrm{OH}$, vs. " $\mathrm{O}_{3}$-dominant", in which $80-90 \%$ of substituted dihydrofurans react with $\mathrm{O}_{3}$. Gas-phase products that are unique to the substituted dihydrofuran chemistry are identified. The impact of ozonolysis of substituted dihydrofurans on the particle-phase product distribution from the photooxidation of dodecane is investigated by comparing intensities of certain ions that are indicative of ozonolysis chemistry. We also develop a detailed mechanism with the incorporation of substituted dihydrofuran chemistry and simulate the effect of this reaction channel on SOA yield from the photooxidation of dodecane.

\section{Experimental}

Experiments were conducted in the new Caltech dual $24-\mathrm{m}^{3}$ Environmental Chamber, in which the temperature $(T)$ and relative humidity (RH) are automatically controlled. Prior to each experiment, the Teflon chambers were flushed with clean, dry air for $24 \mathrm{~h}$ until the particle number concentration was $<10 \mathrm{~cm}^{-3}$ and volume concentration $<0.01 \mu^{3} \mathrm{~cm}^{-3}$. Seed aerosol was injected into the chamber by atomizing $0.015 \mathrm{M}$ aqueous ammonium sulfate solution to provide sufficient surface area for the partition of semivolatile products. Hydrogen peroxide $\left(\mathrm{H}_{2} \mathrm{O}_{2}\right)$ was used for the $\mathrm{OH}$ source by evaporating 85 and $226 \mu \mathrm{L}$ of $50 \mathrm{wt} \%$ aqueous solution into the chamber with $5 \mathrm{~L} \mathrm{~min}^{-1}$ of purified air for $\sim 110 \mathrm{~min}$, resulting in an approximate starting $\mathrm{H}_{2} \mathrm{O}_{2}$ concentration of 1.5 and $4 \mathrm{ppm}$, respectively, under high- and low- $\mathrm{NO}_{\mathrm{x}}$ conditions. The $4 \mathrm{ppm} \mathrm{H}_{2} \mathrm{O}_{2}$ concentration employed in low$\mathrm{NO}_{\mathrm{x}}$ experiments creates a $\mathrm{RO}_{2}+\mathrm{HO}_{2}$ dominant reaction regime. We replaced $\mathrm{H}_{2} \mathrm{O}_{2}$ with nitrous acid (HONO) as the $\mathrm{OH}$ source for one experiment in order to minimize the formation of ozone. HONO was prepared by dropwise addition of $15 \mathrm{~mL}$ of $1 \mathrm{wt} \% \mathrm{NaNO}_{2}$ into $30 \mathrm{~mL}$ of $10 \mathrm{wt} \%$ $\mathrm{H}_{2} \mathrm{SO}_{4}$ in a glass bulb and introduced into the chambers with $5 \mathrm{~L} \mathrm{~min}^{-1}$ of purified air for $\sim 40 \mathrm{~min}$. To minimize the vapor-phase wall loss along the injection line, $60 \mu \mathrm{L}$ of dodecane (Sigma-Aldrich, $98 \%$ purity) was injected into a glass bulb, which was connected directly into the Teflon chamber via a $1 / 4$ in. inside diameter (i.d.). Swagelock to NPT fitting located on a Teflon plate. Heated $5 \mathrm{~L} \mathrm{~min}^{-1}$ of purified air flowed through the glass bulb into the chamber for $30 \mathrm{~min}$, introducing $\sim 200 \mathrm{ppb}$ dodecane into the chamber. After $\sim 1 \mathrm{~h}$ of mixing, photooxidation was initiated by irradiating the chamber with black lights with output wavelength ranging from 300 to $400 \mathrm{~nm}$.

Experiments were carried out under conditions in which the peroxy radicals formed from the initial $\mathrm{OH}$ reaction with dodecane react either essentially exclusively with NO (socalled high $\mathrm{NO}_{\mathrm{x}}$ ) (Exp. 1, 2, 3, 4, and 5) or essentially 
Table 1. Experimental conditions for the photooxidation of dodecane.

\begin{tabular}{|c|c|c|c|c|c|c|c|c|c|}
\hline & Exp. & $\begin{array}{l}T_{0} \\
(\mathrm{~K})\end{array}$ & $\begin{array}{l}\mathrm{RH}_{0} \\
(\%)\end{array}$ & $\begin{array}{l}\mathrm{HC}_{0} \\
(\mathrm{ppb})\end{array}$ & $\begin{array}{l}(\mathrm{NO})_{0} \\
(\mathrm{ppb})\end{array}$ & $\begin{array}{l}\left(\mathrm{NO}_{2}\right)_{0} \\
(\mathrm{ppb})\end{array}$ & $\begin{array}{l}\left(\mathrm{O}_{3}\right)_{0} \\
(\mathrm{ppb})\end{array}$ & $\begin{array}{l}\text { Initial } \\
\text { seed vol. } \\
\left(\mu \mathrm{m}^{3} \mathrm{~m}^{-3}\right)\end{array}$ & $\begin{array}{l}\text { Additional } \\
\text { NO inj. } \\
\left(\mathrm{ppb} \mathrm{h}^{-1}\right) \times(\mathrm{h})\end{array}$ \\
\hline \multirow{5}{*}{ High $\mathrm{NO}_{\mathrm{x}}^{\mathrm{a}}$} & 1 & $\sim 300$ & $\sim 3$ & 208 & 430 & 576 & $<\mathrm{DL}^{\mathrm{g}}$ & 18 & - \\
\hline & 2 & $\sim 300$ & $\sim 3$ & 208 & 287 & 12 & $\sim 2$ & 24 & $\mathrm{Y}^{\mathrm{c}}$ \\
\hline & 3 & $\sim 300$ & $\sim 11$ & 206 & 45 & 33 & $\sim 2$ & 30 & $\mathrm{Y}^{\mathrm{d}}$ \\
\hline & 4 & $\sim 300$ & $\sim 20$ & 178 & 38 & 156 & $\sim 2$ & 28 & $\mathrm{Y}^{\mathrm{e}}$ \\
\hline & 5 & $\sim 300$ & $\sim 55$ & 214 & 69 & 30 & $\sim 2$ & 43 & $\mathrm{Y}^{\mathrm{f}}$ \\
\hline \multirow{3}{*}{ Low $\mathrm{NO}_{\mathrm{x}}^{\mathrm{b}}$} & 6 & $\sim 300$ & $\sim 3$ & 208 & $<\mathrm{DL}$ & $<\mathrm{DL}$ & $<\mathrm{DL}$ & 19 & - \\
\hline & 7 & $\sim 300$ & $\sim 3$ & 214 & $<\mathrm{DL}$ & $<\mathrm{DL}$ & 32.6 & 25 & - \\
\hline & 8 & $\sim 300$ & $\sim 55$ & 216 & $<\mathrm{DL}$ & $<\mathrm{DL}$ & $<\mathrm{DL}$ & 58 & - \\
\hline
\end{tabular}

${ }^{a}$ Under high-NO $\mathrm{x}_{\mathrm{x}}$ conditions, the simulated $\mathrm{NO}$ concentration $(>5 \mathrm{ppb})$ is at least 4 orders of magnitude higher than $\mathrm{RO}_{2}\left(<5 \times 10^{7} \mathrm{molecules}^{-3}\right)$. Over $99 \%$ of $\mathrm{RO}_{2}$ is predicted to react with NO.

${ }^{\mathrm{b}}$ Under low- $\mathrm{NO}_{\mathrm{x}}$ conditions, the simulated $\mathrm{HO}_{2}$ concentration $\left(\sim 1 \times 10^{10}\right.$ molecules cm $\left.{ }^{-3}\right)$ is $\sim 20$ times higher than $\mathrm{RO}_{2}\left(\sim 5 \times 10^{8}\right.$ molecules cm $\left.{ }^{-3}\right)$. $\mathrm{RO}_{2}+\mathrm{HO}_{2}$ dominates the fate of $\mathrm{RO}_{2}$.

${ }^{c}$ NO source was controlled at $100 \mathrm{ppbh}^{-1}$ for the first $7 \mathrm{~h}$ of reaction and then $25 \mathrm{ppbh}^{-1}$ for the remainder of the reaction.

$\mathrm{d}$ NO source was controlled at $25 \mathrm{ppbh}^{-1}$ over the course of the experiment.

e NO source was controlled at $30 \mathrm{pph} \mathrm{h}^{-1}$ for the first $3 \mathrm{~h}$ of reaction and then $100 \mathrm{ppb} \mathrm{h}^{-1}$ for the next $1 \mathrm{~h}$ of reaction and then back to $30 \mathrm{ppbh}{ }^{-1}$ for the remainder of the reaction.

${ }^{\mathrm{f}} \mathrm{NO}$ source was controlled at $50 \mathrm{ppbh}^{-1}$ over the course of the experiment.

$\mathrm{g}$ Detection limits (DL) for $\mathrm{O}_{3}, \mathrm{NO}$, and $\mathrm{NO}_{2}$ are $0.5 \mathrm{ppb}, 0.4 \mathrm{ppb}$, and $0.4 \mathrm{ppb}$, respectively. $\mathrm{H}_{2} \mathrm{O}_{2}$ has an interference on the $\mathrm{O}_{3}$ detection, increasing the $\mathrm{O}_{3}$ monitor readout by $\sim 2-3 \mathrm{ppb}$ in the current study.

exclusively with $\mathrm{HO}_{2}$ (so-called low $\mathrm{NO}_{\mathrm{x}}$ ) (Exp. 6, 7, and 8). For each condition, $\mathrm{O}_{3}$-dominant vs. $\mathrm{OH}$-dominant environments were generated by varying the $\mathrm{OH}$ source, initial $\mathrm{NO}, \mathrm{NO}_{2}$, and $\mathrm{O}_{3}$ concentrations, as well as the additional NO injection rate during the irradiation period (Table 1). The ozonolysis vs. OH oxidation of substituted dihydrofuran is calculated to be equally competitive when the ratio of $\mathrm{O}_{3}$ to $\mathrm{OH}$ concentration is $6.3 \times 10^{4}: 1$ (approximately $2.6 \mathrm{ppb}$ $\mathrm{O}_{3}$ vs. $1.0 \times 10^{6}$ molecules $\mathrm{cm}^{-3} \mathrm{OH}$ ). Under low- $\mathrm{NO}_{\mathrm{x}}$ conditions, $\mathrm{NO}, \mathrm{NO}_{2}, \mathrm{NO}_{\mathrm{x}}$, and $\mathrm{O}_{3}$ were below detection limits, and no ozone formation was observed over the course of $20 \mathrm{~h}$ experiments. $\mathrm{OH}$ oxidation of dihydrofuran is dominant with average $\mathrm{OH}$ concentrations of $1.8 \times 10^{6}$ and $1.5 \times 10^{6}$ molecules $\mathrm{cm}^{-3}$, respectively, in Exp. 6 and 8. OH concentration is calculated by optimal fitting of the exponential decay of the GC-FID (gas chromatograph with flame ionization detection)-measured dodecane temporal profile. In order to evaluate the effect of the ozonolysis of dihydrofuran chemistry on the dodecane SOA formation under low- $\mathrm{NO}_{\mathrm{x}}$ conditions, additional $\sim 30 \mathrm{ppb}$ of ozone was injected into the chamber before the onset of irradiation (Exp. 7). Under high- $\mathrm{NO}_{\mathrm{x}}$ conditions, $\mathrm{HONO}$ was used as the $\mathrm{OH}$ source for the OH-dominant environment (Exp. 1). Double HONO injection was carried out in order to fully consume dodecane (before the onset and after $\sim 3 \mathrm{~h}$ of irradiation). The average $\mathrm{OH}$ concentration is $\sim 5.0 \times 10^{6}$ molecules $\mathrm{cm}^{-3}$, whereas $\mathrm{O}_{3}$ peaks at $8 \mathrm{ppb}$ after 60 min of photooxidation and rapidly decays to $\sim 0 \mathrm{ppb}$ within $2 \mathrm{~h}$. In this case, $>73 \%$ of dihydrofuran is oxidized by $\mathrm{OH}$ over the course of Exp. 1. $\mathrm{An} \mathrm{O}_{3}$ dominant environment was generated by injecting NO (38$287 \mathrm{ppb})$ and $\mathrm{NO}_{2}(12-156 \mathrm{ppb})$ before the onset of irradia- tion. Continuous NO injection with a certain flow rate (20$100 \mathrm{ppb} \mathrm{h}^{-1}$ ) was conducted over the course of experiments to reach a sufficient amount of $\mathrm{O}_{3}$ and to maintain high- $\mathrm{NO}_{\mathrm{x}}$ levels. Under experimental conditions in Exp. 2, 3, 4, and 5, the average $\mathrm{OH}$ concentrations are calculated to be $1.7 \times 10^{6}$, $2.0 \times 10^{6}, 1.4 \times 10^{6}$, and $1.3 \times 10^{6}$ molecules $\mathrm{cm}^{-3}$, respectively, and the maximum $\mathrm{O}_{3}$ mixing ratios are 20,380, 150, and $250 \mathrm{ppb}$, respectively. As a result, $\sim 82, \sim 96, \sim 97$, and $\sim 98 \%$ of dihydrofuran reacts with $\mathrm{O}_{3}$ when dihydrofuran peaks after $\sim 3 \mathrm{~h}$ of photooxidation. High-humidity experiments were also carried out as a set of control experiments (Exp. 4, 5, and 8) addressing the role of water vapor in the heterogeneous interconversion between $\delta$-hydroxycarbonyls and substituted dihydrofurans.

A suite of instruments was used to investigate gas- and particle-phase chemistry. $T, \mathrm{RH}, \mathrm{NO}, \mathrm{NO}_{\mathrm{x}}$, and $\mathrm{O}_{3}$ were continuously monitored. Dodecane concentration was monitored by taking hourly samples at $\sim 0.13 \mathrm{~L} \mathrm{~min}^{-1}$ of chamber air for 3 min onto a Tenax adsorbent, which was loaded into the inlet of a GC-FID (Agilent $6890 \mathrm{~N}$ ), desorbed at $275^{\circ} \mathrm{C}$ for $13 \mathrm{~min}$, and then injected onto an HP-5 column $(15 \mathrm{~m} \times 0.53 \mathrm{~mm}$ i.d. $\times 1.5 \mu \mathrm{m}$ thickness, Hewlett-Packard) held at $30^{\circ} \mathrm{C}$. The oven was ramped from 30 to $275^{\circ} \mathrm{C}$ at $10^{\circ} \mathrm{C} \mathrm{min}^{-1}$ and held at $275^{\circ} \mathrm{C}$ for $5 \mathrm{~min}$. The retention time for dodecane is $\sim 27.5 \mathrm{~min}$. The gas-phase species were monitored using a custom-modified Varian 1200 triplequadrupole chemical ionization mass spectrometer (CIMS) (Crounse et al., 2006; Paulot et al., 2009). In negative mode operation, $\mathrm{CF}_{3} \mathrm{O}^{-}$was used as the reagent ion to cluster with an analyte such as hydroperoxide or acid $[R]$, producing $\left[R \cdot \mathrm{CF}_{3} \mathrm{O}\right]^{-}$or $m / z[M+85]^{-}$, where $M$ is the molecular 


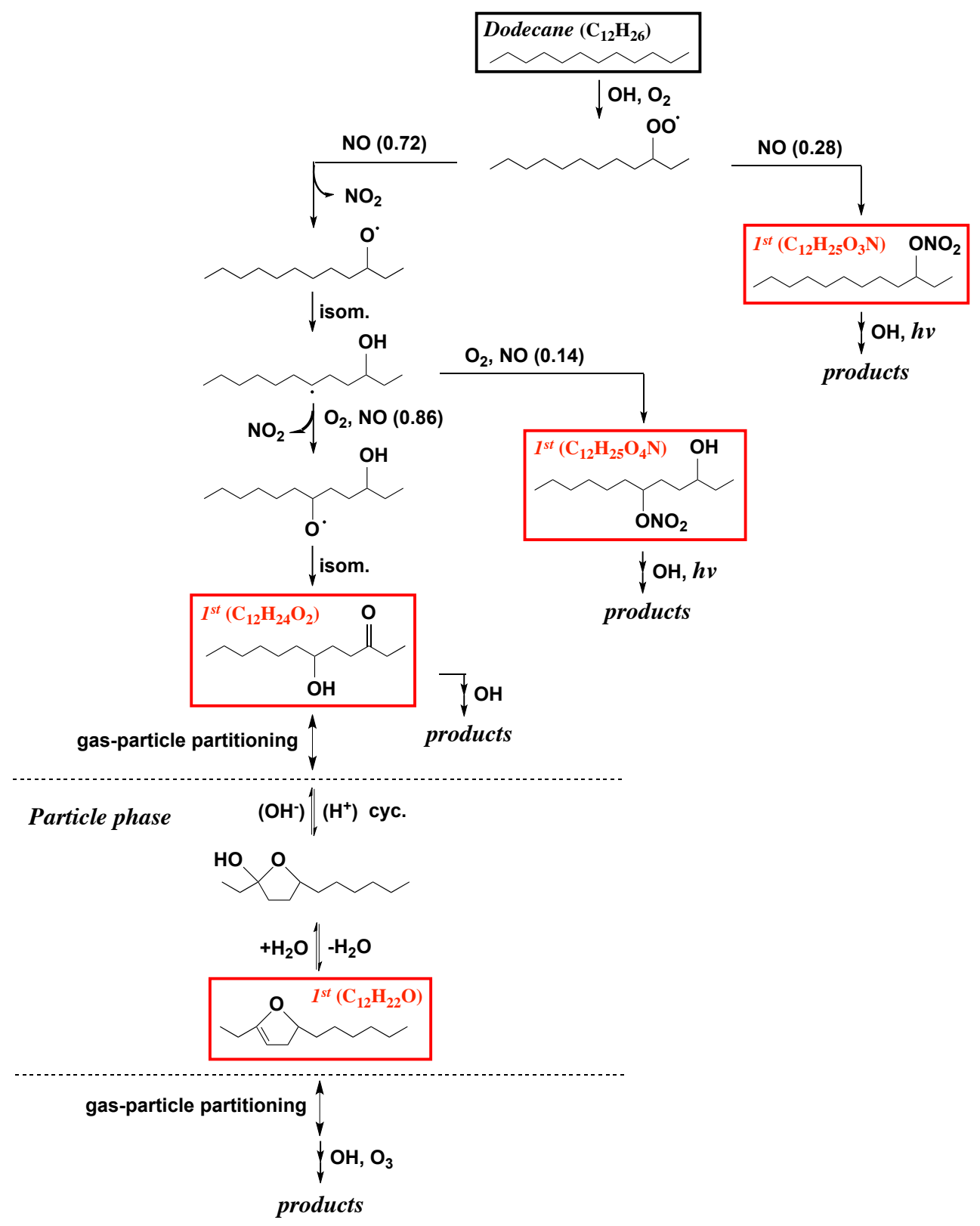

Fig. 1a. Schematic mechanism for the photooxidation of dodecane under high- $\mathrm{NO}_{\mathrm{x}}$ conditions. Note that only first-generation products are shown here. The boxes indicate compounds and associated reaction pathways incorporated in the model simulation.

weight of the analyte. For more strongly acidic species $[\mathrm{H} \cdot \mathrm{X}]$, the transfer product, $[\mathrm{H} \cdot \mathrm{X} \cdot \mathrm{F}]^{-}$or $m / z[M+19]^{-}$, is formed during ionization. Carboxylic acids tend to have contributions to both the transfer and cluster product, in which case the overall signal of a compound is considered as the sum of the two product signals. In positive-mode operation, an analyte $[R]$ can undergo proton transfer reaction, producing an ion in the form of $[R \cdot \mathrm{H}]^{+}$, and/or react with $n$ positively charged water clusters to form a cluster in the form of $\left[\left(\mathrm{H}_{2} \mathrm{O}\right)_{n} \cdot R \cdot \mathrm{H}\right]^{+}$. Positive mode is employed in this study for tracking less polar compounds, such as the substituted dihydrofuran.

Particle size distribution and number concentration were measured by a cylindrical differential mobility analyzer (DMA, TSI Model 3081) coupled to a condensation particle counter (TSI Model 3010). The protocol for applying particle wall loss correction to DMA measured SOA growth data is described in the Supplement. Real-time particle mass spectra were collected continuously by an Aerodyne highresolution time-of-flight aerosol mass spectrometer (DeCarlo et al., 2006; Canagaratna et al., 2007). The AMS switched 


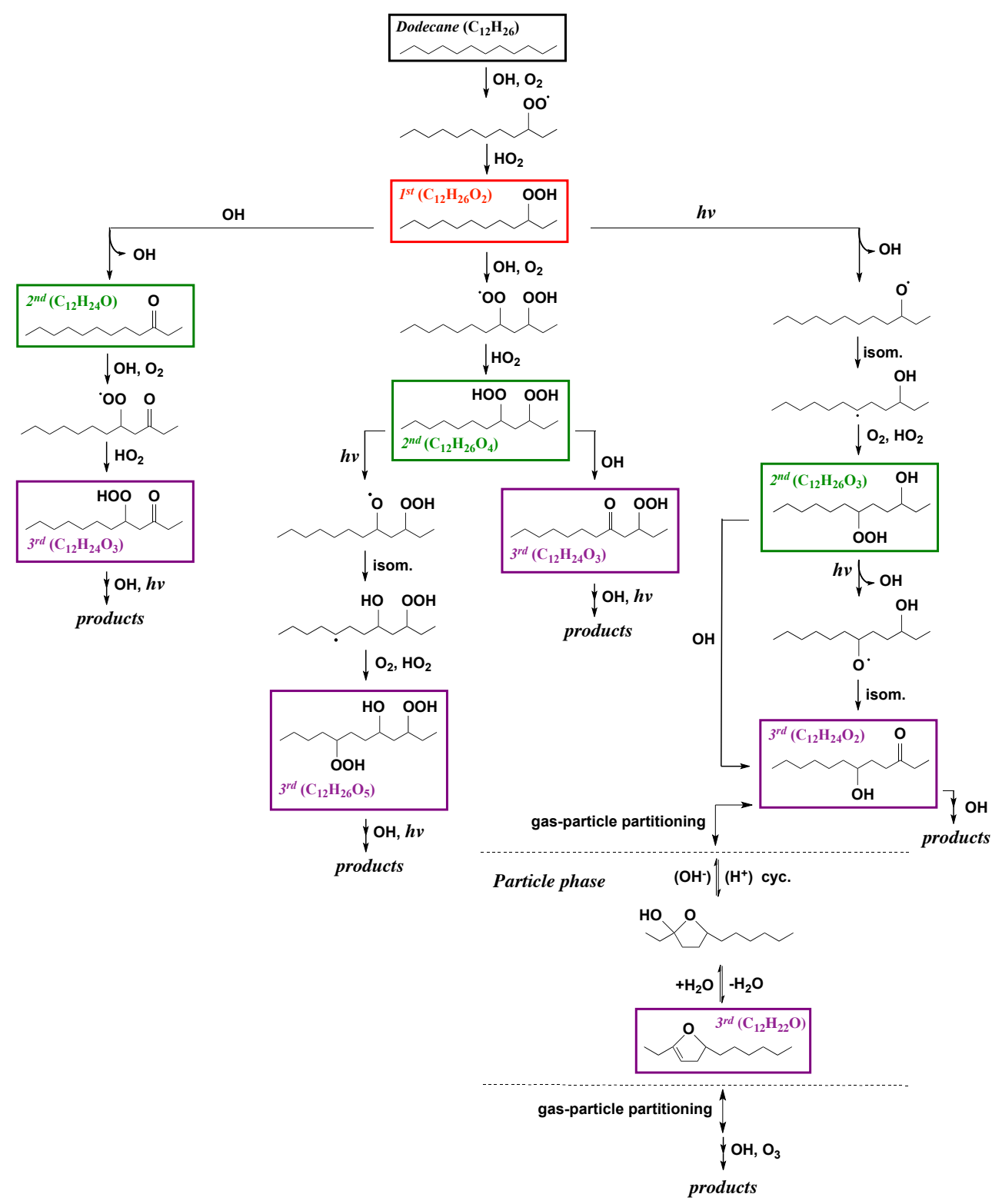

Fig. 1b. Schematic mechanism for the photooxidation of dodecane under low- $\mathrm{NO}_{\mathrm{x}}$ conditions. Note that only the first three generations of products are shown here. The boxes indicate compounds and associated reaction pathways incorporated in the model simulation.

once every minute between the high-resolution "W mode' and the lower resolution, higher sensitivity "V mode". The V mode was utilized for quantification, as the higher $m / z$ values exhibit a more favorable signal-to-noise ratio. The $\mathrm{W}$ mode was used for ion identification and clarification. Detailed AMS data analysis protocols can be found in the Supplement.

\section{Chemical mechanism}

A photochemical mechanism was used to simulate the gasphase photochemistry of $\mathrm{NO}_{\mathrm{x}}, \mathrm{HO}_{\mathrm{x}}$, and $\mathrm{O}_{3}$ corresponding to the experimental conditions. Reactions and corresponding reaction rate constants are listed in Tables S1-S3 in the Supplement. Photolysis rate constants are calculated using the irradiance spectrum measured for the chamber UV lights as well as absorption cross sections and quantum yields from Sander et al. (2011).

The kinetic scheme for the gas-phase $\mathrm{OH}$-initiated oxidation of dodecane and the further $\mathrm{OH}$ oxidation of multigenerational products was developed primarily based on the Master Chemical Mechanism v3.2 (MCM v3.2, http: $/ / \mathrm{mcm}$.leeds.ac.uk/MCM/). Products identified in Lim and Ziemann $(2005 ; 2009 \mathrm{a}, \mathrm{b}, \mathrm{c})$ that are not in MCM are 
also included here. The kinetic scheme was incorporated in the photochemical model to estimate yields of particlephase products generated in the chamber. A simplified flow chart illustrating the mechanism for the multigeneration gasphase chemistry is shown in Fig. 1a, b. In general, the $\mathrm{OH}-$ initiated oxidation of dodecane leads to $\mathrm{RO}_{2}$, the fate of which controls the distribution of further generation products. When sufficient $\mathrm{NO}_{\mathrm{x}}$ is present (the concentration of NO, i.e., $>5 \mathrm{ppb}$, is at least 4 orders of magnitude higher than $\mathrm{RO}_{2}$, i.e., $<5 \times 10^{7}$ molecules $\mathrm{cm}^{-3}$ ), over $99 \%$ of $\mathrm{RO}_{2}$ reacts with $\mathrm{NO}$, leading to $\mathrm{RO}$ or alkyl nitrate $\left(\mathrm{RONO}_{2}\right)$. The branching ratios for the production of $\mathrm{RO}$ and $\mathrm{RONO}_{2}$ are obtained from Jordan et al. (2008). RO can isomerize through a $1,5-\mathrm{H}$-atom shift to a $\delta$-hydroxyalkyl radical, react with $\mathrm{O}_{2}$, or undergo fragmentation. The alkyl nitrate formed either undergoes photolysis or reacts with $\mathrm{OH}$ via $\mathrm{H}$-atom abstraction from a $\mathrm{C}$ atom or reacts with $\mathrm{OH}$ via $\mathrm{H}$-atom abstraction from a $\mathrm{C}$ atom with a $-\mathrm{ONO}_{2}$ group attached to produce a $-\mathrm{C}=\mathrm{O}$ group. The $\delta$-hydroxyalkyl radical reacts with $\mathrm{O}_{2}$ and then $\mathrm{NO}$ and undergoes another isomerization to produce a $\delta$-hydroxycarbonyl. At sufficiently low $\mathrm{NO}_{\mathrm{x}}$ concentrations, the simulated $\mathrm{HO}_{2}$ concentration $\left(\sim 1 \times 10^{10}\right.$ molecules $\left.\mathrm{cm}^{-3}\right)$ is $\sim 20$ times higher than $\mathrm{RO}_{2}$ $\left(\sim 5 \times 10^{8}\right.$ molecules $\left.\mathrm{cm}^{-3}\right) . \mathrm{RO}_{2}+\mathrm{HO}_{2}$ dominates the fate of $\mathrm{RO}_{2}$, producing a hydroperoxide $(\mathrm{ROOH})$. Further oxidation of $\mathrm{ROOH}$ involves the photolysis of the $-\mathrm{OOH}$ group, $\mathrm{H}$-atom abstraction, and the $\mathrm{OH}$ oxidation of a $\mathrm{C}$ atom with a $-\mathrm{OOH}$ group attached to produce $\mathrm{a}-\mathrm{C}=\mathrm{O}$ group. Products through eight generations of oxidation are included in the mechanism, although only the formation of the first three generations of products is illustrated in Fig. 1. The reaction rate constants are obtained from MCM v3.2. In the absence of specific data, the photolysis rate constants of the $-\mathrm{OOH},-\mathrm{C}=\mathrm{O}$, and $-\mathrm{ONO}_{2}$ groups on the carbon backbone are assumed to be the same as those for methyl peroxide $\left(\mathrm{CH}_{3} \mathrm{OOH}\right)$, 2-butanol $\left(\mathrm{C}_{3} \mathrm{H}_{7} \mathrm{CHO}\right)$, and $n$-propyl nitrate ( $n$ $\mathrm{CH}_{3} \mathrm{ONO}_{2}$ ).

Cyclization and subsequent dehydration of $\delta$ hydroxycarbonyl to substituted dihydrofuran is a heterogeneous process, including (1) gas-phase diffusion and reactive uptake of $\delta$-hydroxycarbonyl to particles, (2) cyclization of $\delta$-hydroxycarbonyl to cyclic hemiacetal, and (3) dehydration of cyclic hemiacetal to substituted dihydrofuran. (Atkinson et al., 2008; Lim and Ziemann, 2009c). The extent of this heterogeneous process occurring on/in particles has been predicted to predominate over chamber walls (Lim and Ziemann, $2009 \mathrm{c}$ ). In this study, we represent the individual steps of the conversion of $\delta$-hydroxycarbonyl to substituted dihydrofuran by an overall first-order decay rate of $3 \times 10^{-3} \mathrm{~s}^{-1}$. This value is estimated by monitoring the decay of 5-hydroxy-2-pentanone using CIMS in the presence of $20 \mu^{3} \mathrm{~cm}^{-3}\left(\mathrm{NH}_{4}\right) \mathrm{SO}_{4} / \mathrm{H}_{2} \mathrm{SO}_{4}$ seeds at $3 \% \mathrm{RH}$. This assumed decay rate is consistent with those rates measured in previous studies (Cavalli et al., 2000; Martin et al., 2002, Holt et al., 2005; Lim and Ziemann, 2009 c). The equilibrium constant $K$ ( $K=$ [4,5-dihydro-2-methylfuran]/[5-hydroxy2-pentanone]) is estimated to be $\sim 7$ at $3 \% \mathrm{RH}$ from the CIMS measured 5-hydroxy-2-pentanone decay curve, based on the assumption that the decrease in the 5-hydroxy-2pentanone concentration is accompanied by stoichiometric formation of the corresponding 4,5-dihydro-2-methylfuran. Note that although the proportion of the heterogeneous conversion occurring on the chamber walls is unknown, the potential contribution of chamber walls to the particle-phase production of substituted dihydrofuran has been accounted for by employing the measured overall conversion rate in the mechanism.

The substituted dihydrofuran formed evaporates rapidly due to its high volatility and undergoes reactions with $\mathrm{OH}, \mathrm{O}_{3}$, and $\mathrm{NO}_{3}$ in the gas phase (Ziemann and Atkinson, 2012), with reaction rate constants of $2.18 \times 10^{-10}$, $3.49 \times 10^{-15} \mathrm{~cm}^{3}$ molecule ${ }^{-1} \mathrm{~s}^{-1}$, and $1.68 \times 10^{-10} \mathrm{~cm}^{3}$ molecule ${ }^{-1} \mathrm{~s}^{-1}$, respectively (Martin et al., 2002; Atkinson et al., 2008). Reaction with $\mathrm{NO}_{3}$ is not important under the conditions of this study. In general, the $\mathrm{OH}$ addition to an alkyl-substituted dihydrofuran produces either an alkylsubstituted tetrahydrofuran or a carbonyl ester; see Fig. 2a (Martin et al., 2002, Lim and Ziemann, 2005, 2009a, b, c, Jordan et al., 2008). The mechanism for the $\mathrm{O}_{3}$ reaction with an alkyl-substituted dihydrofuran, as shown in Fig. 2b, was developed following the ozonolysis of 4,5-dihydro-2methylfuran (Martin et al., 2002), alkyl vinyl ethers (Thiault et al., 2002; Klotz et al., 2004; Sadezky et al., 2006) and monoterpenes (Jenkin et al., 2000; Jenkin, 2004). The reaction of alkyl-substituted dihydrofuran with $\mathrm{O}_{3}$ involves the addition of $\mathrm{O}_{3}$ to the $\mathrm{C}=\mathrm{C}$ double bond to produce an energy-rich primary ozonide, which rapidly decomposes into two excited Criegee intermediates. The energy-rich Criegee intermediates are either collisionally stabilized or decompose to yield $\mathrm{OH}$ (or $\mathrm{OH}+\mathrm{CO}$ ) and an additional $\alpha$ carbonyl peroxy radical (or peroxy radical). The resulting $\alpha$ carbonyl peroxy radical (or peroxy radical) can undergo the well-established reactions available for peroxy radicals; see Fig. 2b. The stabilized Criegee intermediates are predicted to react primarily with water (Martin et al., 2002), leading to 3-propoxy-nonanal $\left(\mathrm{C}_{12} \mathrm{H}_{22} \mathrm{O}_{3}\right)$ and 3-propoxy-nonanic acid $\left(\mathrm{C}_{12} \mathrm{H}_{22} \mathrm{O}_{3}\right)$, with molar yields of 90 and $10 \%$, respectively. The total yield of 3-propoxy-nonanal is predicted to be $18 \%$, which is close to the yield of succinaldehydic acid methyl ester $(23 \%)$ from the ozonolysis of 4,5-dihydro-2-methylfuran (Martin et al., 2002).

We consider SOA formation by dodecane photooxidation, including heterogeneous formation of substituted dihydrofuran and its subsequent reaction with $\mathrm{OH} / \mathrm{O}_{3}$. Gas-particle equilibrium partitioning of semivolatile products is assumed. The branching ratio and vapor pressure $\left(\mathrm{P}_{L, i}^{0} \mathrm{~atm}^{-1}\right)$ at $300 \mathrm{~K}$ (predicted by SIMPOL.1; Pankow and Asher, 2008) of each product from the $\mathrm{OH} / \mathrm{O}_{3}$-initiated oxidation of alkyl-substituted dihydrofuran are labeled in Fig. 2. The corresponding effective saturation concentrations 


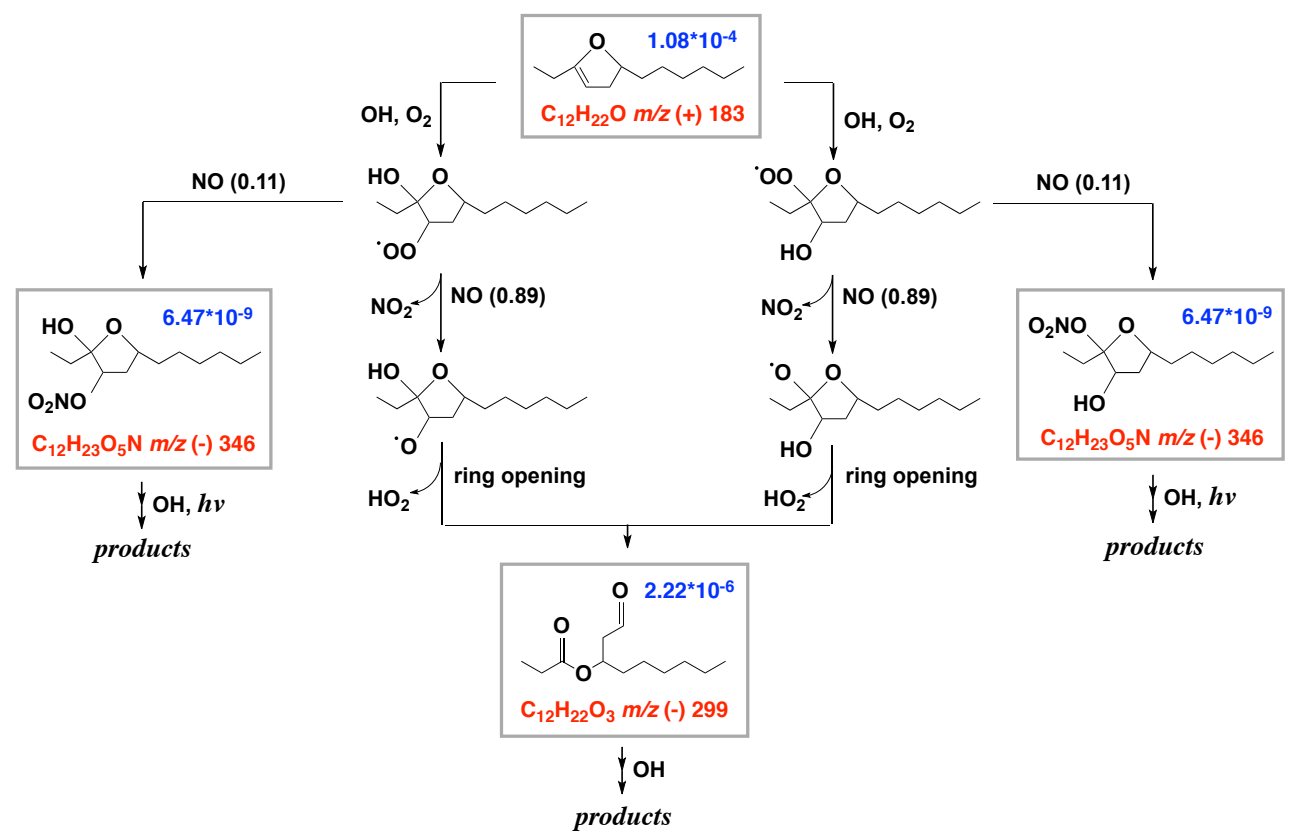

Fig. 2a. Proposed mechanism for the $\mathrm{OH}$-initiated oxidation of alkyl-substituted dihydrofuran under high- $\mathrm{NO}_{\mathrm{x}}$ conditions. The boxes indicate compounds or reaction pathways incorporated in the model simulation. CIMS monitored species have $m / z$ noted in red. Estimated vapor pressure (atm) of each compound is indicated in blue.

$\left(\mathrm{C}^{*}=10^{6} \mathrm{P}_{\mathrm{L}, \mathrm{i}}^{0} \gamma_{i} \bar{M}_{\mathrm{w}} / R T\right)$ range from $7.0 \times 10^{1} \mu \mathrm{g} \mathrm{m}{ }^{-3}$ to $4.7 \times 10^{4} \mu \mathrm{g} \mathrm{m}^{-3}$, for which approximately $0.1 \% \sim 41.7 \%$ of these products are in the particle phase at an organic loading of $\sim 50 \mu \mathrm{g} \mathrm{m}^{3}$. Compounds with the lowest volatility $\left(\sim 10^{-9} \mathrm{~atm}\right)$ are produced mostly from the $\mathrm{RO}_{2}+\mathrm{NO} \rightarrow \mathrm{RONO}_{2}$ reaction, the branching ratio of which ranges from 0.11 to 0.28 . As a result, the total amount of organic nitrates in the particle phase is relatively high; see Fig. 9c. Compounds generated from the $\mathrm{RO}_{2}+\mathrm{NO} \rightarrow \mathrm{RO}+\mathrm{NO}_{2}$ reaction have higher molar yields $(0.72-0.89)$. But they are too volatile $\left(\sim 10^{-6}-10^{-7} \mathrm{~atm}\right)$ to partition significantly into the particle phase. The stabilized Criegee intermediate reaction with water is predicted to predominate over reaction with $\mathrm{NO} / \mathrm{NO}_{2}$ at $\mathrm{RH}>3 \%$. The ester containing carboxylic acid $\left(\mathrm{C}_{12} \mathrm{H}_{22} \mathrm{O}_{4}\right)$ is predicted to be present in the particle phase due to its sufficiently low volatility $\left(\sim 10^{-8}\right.$ atm); see Fig. $9 \mathrm{c}$.

\section{Results and discussion}

In this section, we seek to evaluate the impact of substituted dihydrofuran chemistry on dodecane SOA formation as follows: (1) predict the yield of alkyl-substituted dihydrofuran from the photooxidation of dodecane under both high- and low- $\mathrm{NO}_{\mathrm{x}}$ conditions, and the fraction of alkyl-substituted dihydrofuran that reacts with $\mathrm{O}_{3}$ in the $\mathrm{O}_{3}$-dominant regime (Sect. 4.1); (2) measure the time-dependent evolution of cyclic hemiacetal and alkyl-substituted dihydrofuran at $3 \%$,
10, 20, and 50\% RH (Sect. 4.2); (3) propose gas-phase products that are unique to dihydrofuran chemistry based on the CIMS speciation (Section 4.3); (4) compare particle-phase chemical composition under $\mathrm{OH}$-dominant vs. $\mathrm{O}_{3}$-dominant environments via identifying AMS measured ions representative of dihydrofuran oxidation products (Sect. 4.4); and (5) estimate the change in SOA yield and elemental composition by incorporating the complete substituted-dihydrofuran formation and removal pathways into the dodecane SOA prediction model (Sect. 4.5).

\subsection{Predicted substituted dihydrofuran formation and reaction with ozone in the dodecane system}

To what extent is the formation of substituted dihydrofuran and its subsequent chemistry important in the formation of dodecane SOA? A mechanism simulation was conducted, with initial conditions similar to those employed in the chamber (Table 1), i.e., $200 \mathrm{ppb}$ dodecane, $1.5 \mathrm{ppm}$ $\mathrm{H}_{2} \mathrm{O}_{2}, 100 \mathrm{ppb} \mathrm{O}_{3}$, and $100 \mathrm{ppb}+30 \mathrm{ppb} \mathrm{h}^{-1}$ NO for high$\mathrm{NO}_{\mathrm{x}}$ conditions and $200 \mathrm{ppb}$ dodecane, 4 ppm $\mathrm{H}_{2} \mathrm{O}_{2}, 100 \mathrm{ppb}$ $\mathrm{O}_{3}$, and $0 \mathrm{ppb} \mathrm{NO}_{\mathrm{x}}$ for low- $\mathrm{NO}_{\mathrm{x}}$ conditions. Figure 3 shows the predicted mass distribution of $\delta$-hydroxycarbonyl, alkylsubstituted dihydrofuran, together with other products of the same generation. $\delta$-hydroxycarbonyl is predicted to account for $>90 \%$ total organic mass of first-generation products under high- $\mathrm{NO}_{\mathrm{x}}$ conditions (see Fig. $3 \mathrm{a}(\mathrm{H})$ ), but $<5 \%$ to the total organic mass of the third-generation products under low-NO $\mathrm{N}_{\mathrm{x}}$ conditions (see Fig. 3a (L)). Inclusion of the 


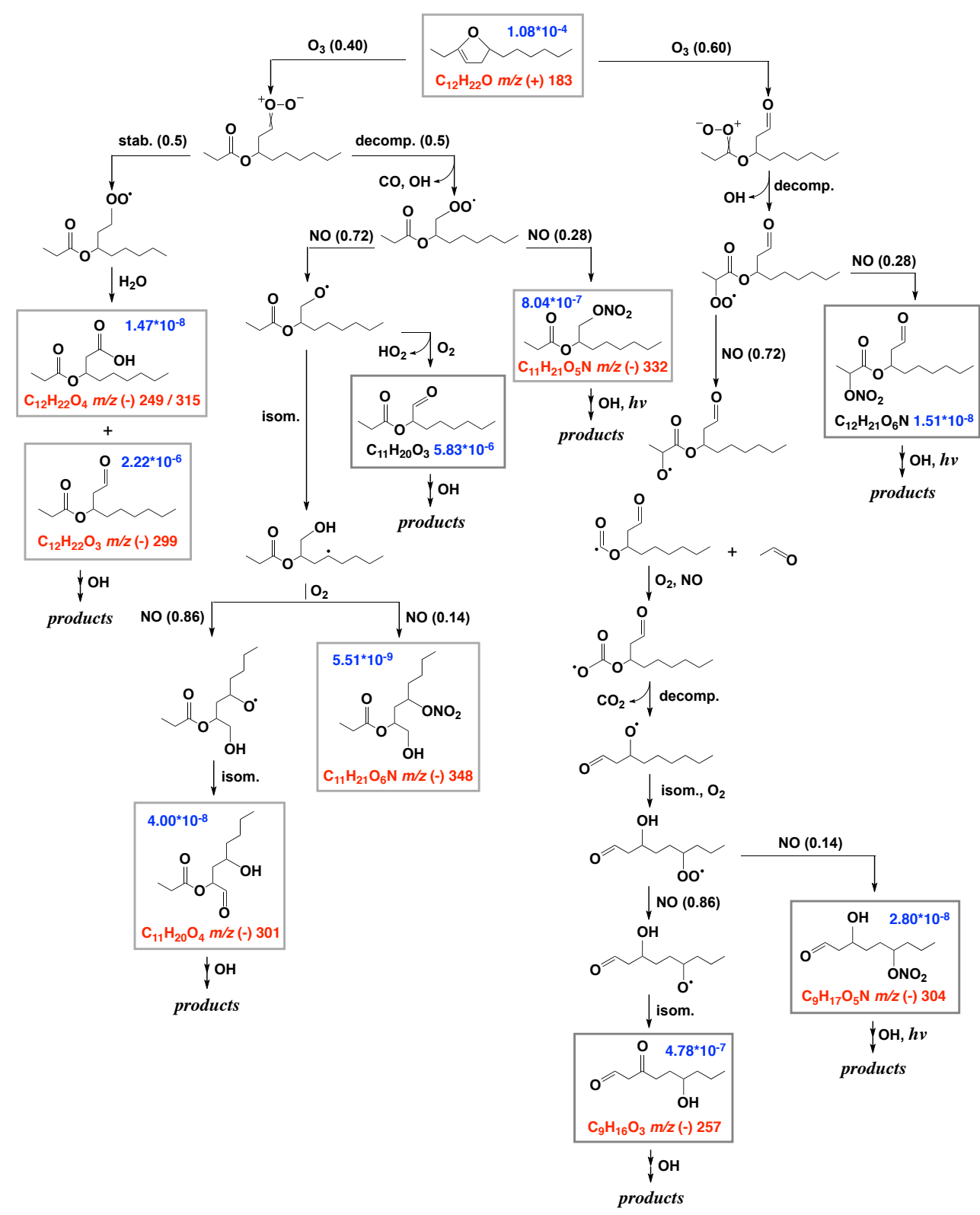

Fig. 2b. Proposed mechanism for the ozonolysis of alkyl-substituted dihydrofuran under high- $\mathrm{NO}_{\mathrm{x}}$ conditions. The boxes indicate compounds or reaction pathways incorporated in the model simulation. CIMS monitored species have $m / z$ noted in red. Estimated vapor pressure (atm) of each compound is indicated in blue.

heterogeneous conversion pathway from $\delta$-hydroxycarbonyl to alkyl-substituted dihydrofuran is predicted to result in a rapid consumption of $\delta$-hydroxycarbonyl under dry conditions, as opposed to a slow decay from $\mathrm{OH}$ oxidation. Alkyl-substituted dihydrofuran accounts for up to $70 \%$ of the decay of $\delta$-hydroxycarbonyl, as shown in Fig. 3b $(\mathrm{H})$. As discussed earlier, an ozonolysis-dominant environment occurs for $\mathrm{O}_{3}>3 \mathrm{ppb}$ at a typical $\mathrm{OH}$ concentration of $1.0 \times 10^{6}$ molecules $\mathrm{cm}^{-3}$. In the high- $\mathrm{NO}_{\mathrm{x}}$ simulation case, ozone is predicted to lead to $82-98 \%$ of the total alkyl- substituted dihydrofuran loss over the course of photooxidation; see Fig. 3d (H).

The alkyl-substituted dihydrofuran is not the only product that contains a dihydrofuran structure in the dodecane photooxidation system. The first-generation product 3-dodecyl nitrate under high- $\mathrm{NO}_{\mathrm{x}}$ conditions is an example. Three pathways exist that could produce semivolatile compounds containing a dihydrofuran structure from the further photochemical reaction of 3-dodecyl nitrate: (1) photolysis of the $-\mathrm{ONO}_{2}$ group leads to an alkyl-substituted dihydrofuran, (2) abstraction of an $\mathrm{H}$ atom by $\mathrm{OH}$ potentially leads to an 

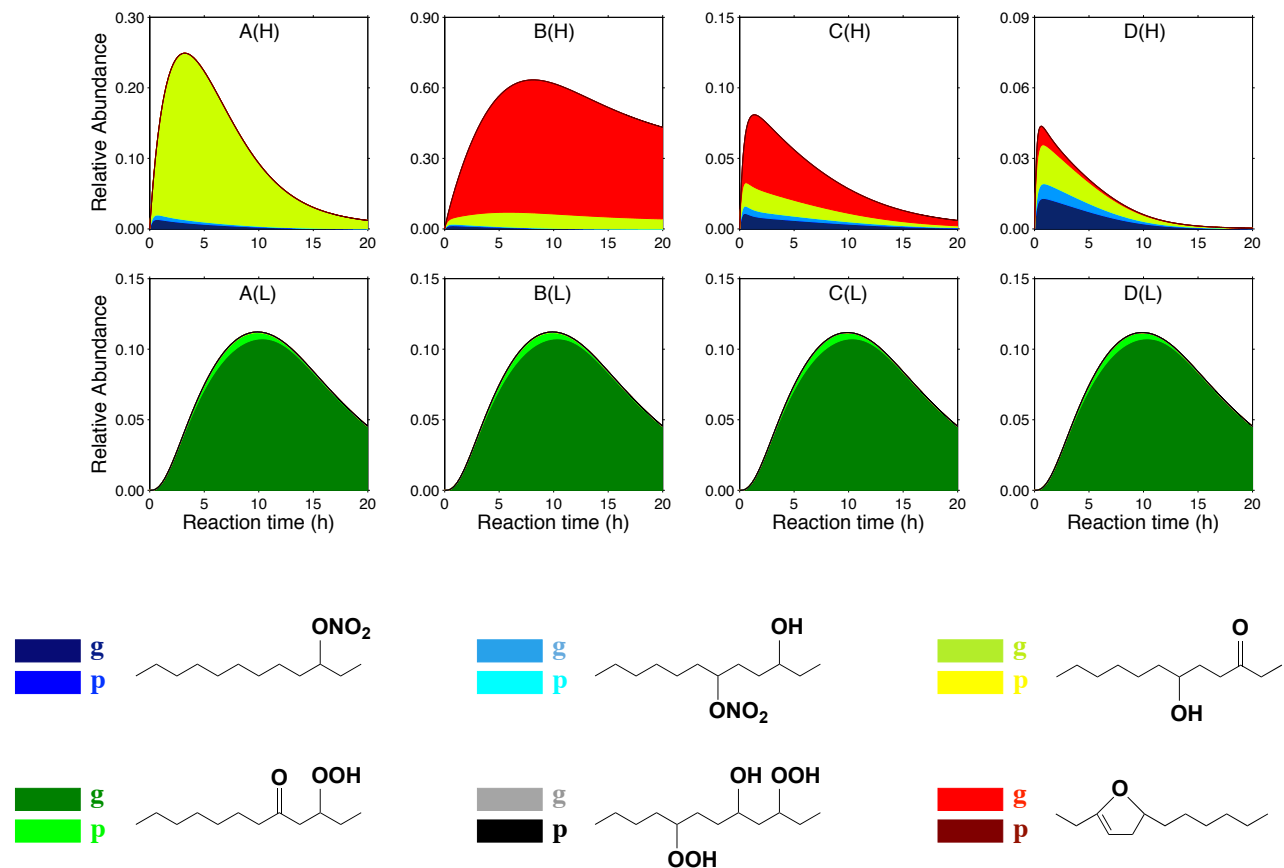

Fig. 3. Model-predicted relative abundance of $\delta$-hydroxycarbonyl and alkyl-substituted dihydrofuran, together with other first-generation products under high- $\mathrm{NO}_{\mathrm{x}}(\mathrm{H})$ and other third-generation products under low- $\mathrm{NO}_{\mathrm{x}}(\mathrm{L})$ conditions in gas $(\mathrm{g})$ and particle $(\mathrm{p})$ phases. All the organic masses are normalized by the initial organic mass ( $\sim 200 \mathrm{ppb}$ dodecane). (A) represents the relative abundance of products without a heterogeneous alkyl-substituted dihydrofuran formation channel, (B) represents the relative abundance of products when the heterogeneous channel is incorporated into the scheme but in the absence of any sink of alkyl-substituted dihydrofuran, (C) represents the relative abundance of products when the $\mathrm{OH}$ oxidation is the only sink of alkyl-substituted dihydrofuran, and (D) represents the relative abundance of products using the complete gas- and particle-phase mechanism.
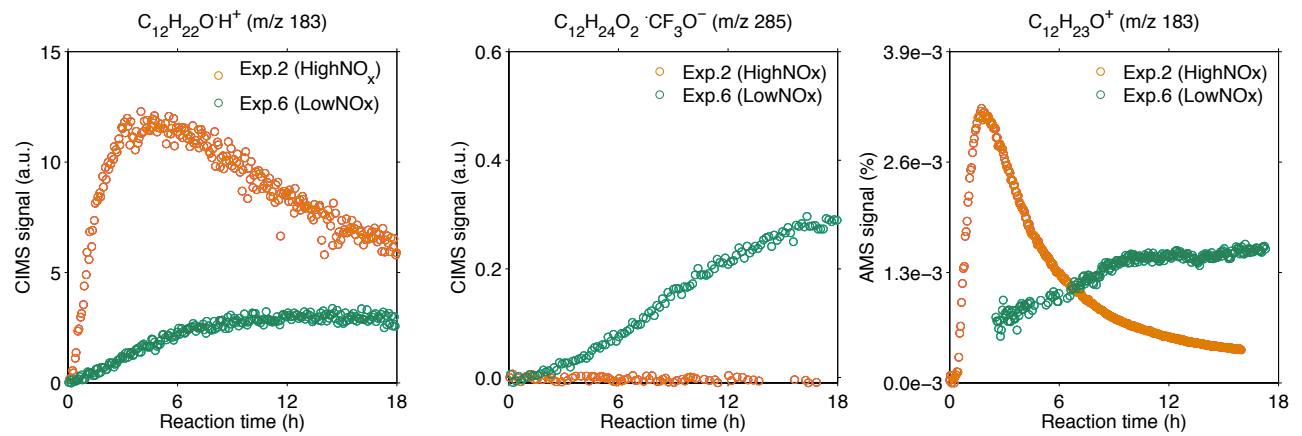

Fig. 4. Temporal profiles of ion $\mathrm{C}_{12} \mathrm{H}_{22} \mathrm{O} \cdot \mathrm{H}^{+}(\mathrm{m} / z=183)$ and $\mathrm{C}_{12} \mathrm{H}_{24} \mathrm{O}_{2} \cdot \mathrm{CF}_{3} \mathrm{O}^{-}(\mathrm{m} / z=285)$ measured by $\mathrm{CIMS}$ and ion $\mathrm{C}_{12} \mathrm{H}_{23} \mathrm{O}^{+}$ $(m / z=183)$ measured by AMS under high- and low- $\mathrm{NO}_{\mathbf{x}}$ conditions. Details of experimental conditions are given in Table 1.

organonitrate-substituted dihydrofuran, and (3) $\mathrm{H}$-atom abstraction from a $\mathrm{C}$ atom with the $-\mathrm{ONO}_{2}$ functional group attached and further $\mathrm{H}$-atom abstraction from a $\mathrm{C}$ atom potentially leads to a carbonyl-substituted dihydrofuran. It is worth noting that the gas-phase ozonolysis of alkyl-substituted dihydrofuran under high- $\mathrm{NO}_{\mathrm{x}}$ conditions contributes to most of the ozonolysis reactions because the alkyl-substituted dihydrofuran is a major first-generation product, as shown in Fig. $3 b(\mathrm{H})$.

\subsection{Formation of cyclic hemiacetals and alkyl-substituted dihydrofuran}

CIMS measurement at $(+) m / z 183$ in positive mode represents the ion $\mathrm{C}_{12} \mathrm{H}_{22} \mathrm{O} \cdot \mathrm{H}^{+}$generated from the proton transfer reaction with alkyl-substituted dihydrofuran $\left(M_{\mathrm{w}}=182\right)$. An additional source of $(+) m / z 183$ is the proton transfer reaction followed by dehydration of hydroxyl dodecanone $\left(M_{\mathrm{W}}=200\right)$, which is also detected as a fluoride cluster product at $(-) m / z 285\left(\mathrm{C}_{12} \mathrm{H}_{24} \mathrm{O}_{2} \cdot \mathrm{CF}_{3} \mathrm{O}^{-}\right)$in negative 

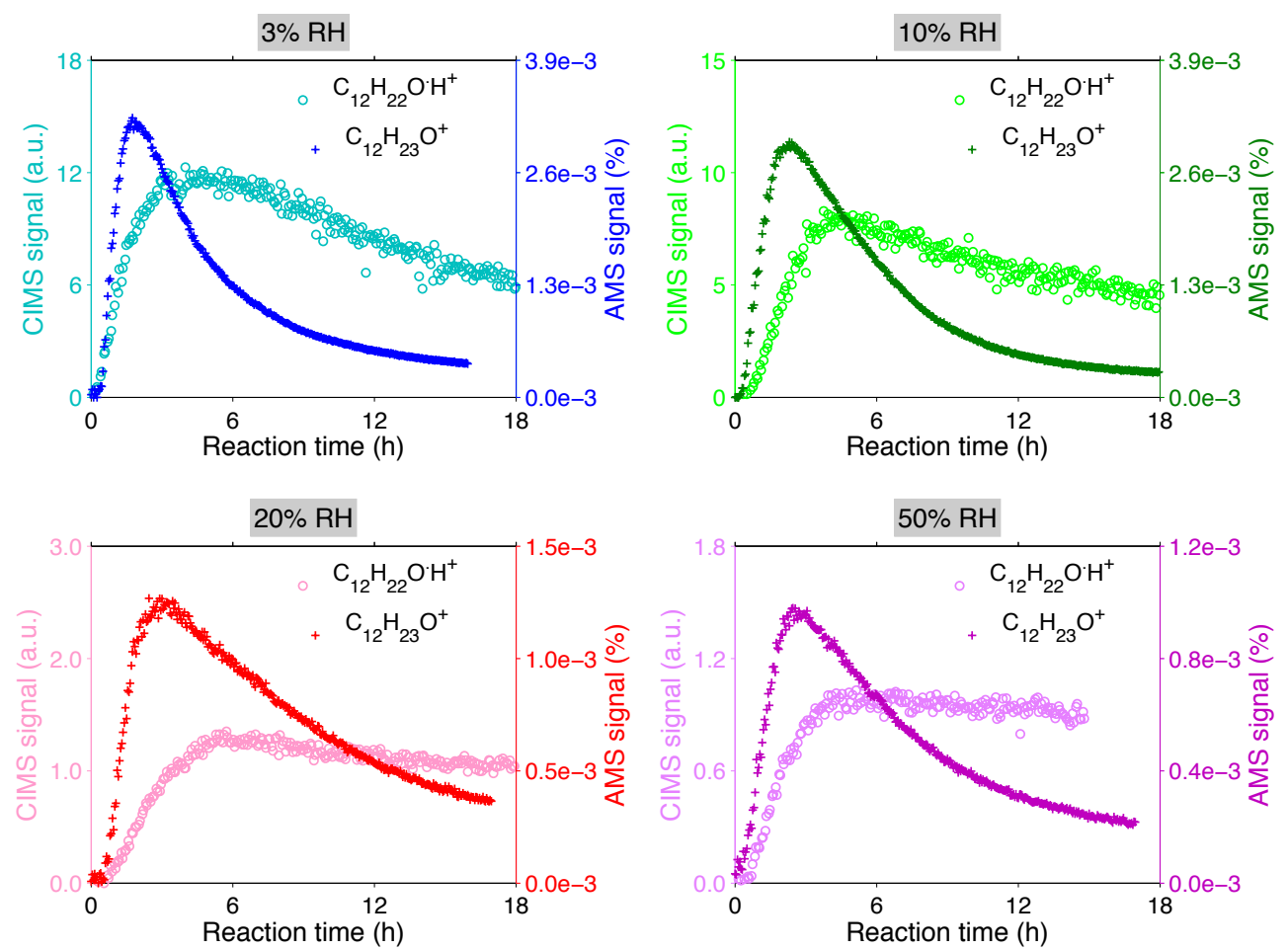

Fig. 5. Time-dependent evolution of ion $\mathrm{C}_{12} \mathrm{H}_{22} \mathrm{O} \cdot \mathrm{H}^{+}(m / z=183)$ measured by CIMS and ion $\mathrm{C}_{12} \mathrm{H}_{23} \mathrm{O}^{+}(m / z=183)$ measured by AMS at 3, 10, 20, and $50 \% \mathrm{RH}$.

mode. Figure 4 shows temporal profiles of $(+) m / z 183$ and $(-) m / z 285$ monitored under both high- and low- $\mathrm{NO}_{\mathrm{x}}$ conditions (Exp. 2 vs. Exp. 6). The $(+) m / z 183$ ion was detected in each of the two experiments, but with distinct timedependent patterns. Under high- $\mathrm{NO}_{\mathrm{x}}$ conditions, $(+) m / z 183$ peaks during the first $3 \mathrm{~h}$ of irradiation, indicating fast formation of alkyl-substituted dihydrofuran, and decays during the next $15 \mathrm{~h}$ of photooxidation. Under low- $\mathrm{NO}_{\mathrm{x}}$ conditions, however, the $(+) m / z 183$ signal eventually reaches a plateau, which is more consistent with the pattern of $(-) m / z 285$. This behavior is consistent with the mechanism prediction that the alkyl-substituted dihydrofuran is formed in significant amounts only under high- $\mathrm{NO}_{\mathrm{x}}$ conditions (Fig. $3 \mathrm{~b}(\mathrm{H})$ ). An alternative explanation for the temporal profiles of $(+)$ $m / z 183$ under low- $\mathrm{NO}_{\mathrm{x}}$ conditions is that this ion is formed by dehydration of the cyclic hemiacetal following protonation in CIMS. The occurrence of a plateau could be indicative of an absence of dehydration in the particle phase due to the lack of an acid catalyst (no $\mathrm{HNO}_{3}$ formation from $\mathrm{NO}_{2}+\mathrm{OH}$ reaction as in the high- $\mathrm{NO}_{\mathrm{x}}$ cases). However, based on the model prediction, cyclic hemiacetal is not likely to accumulate since the formation of its precursor, $\delta$-hydroxycarbonyl, is a minor pathway when the $\mathrm{RO}_{2}+\mathrm{HO}_{2}$ reaction is dominant and the photolysis of the resulting peroxide is not important.

The AMS measured $m / z 183\left(\mathrm{C}_{12} \mathrm{H}_{23} \mathrm{O}^{+}\right)$is the major characteristic ion for cyclic hemiacetal. This ion is produced by the neutral loss of $\mathrm{OH}\left(M_{\mathrm{W}}=17\right)$ from the 2 po- sition in the cyclic hemiacetal $\left(M_{\mathrm{w}}=200\right)$ during electron ionization (Gong et al., 2005; Lim and Ziemann, 2009c). In addition, the $\mathrm{C}_{12} \mathrm{H}_{23} \mathrm{O}^{+}$ion is suggested to be the characteristic fragment of carbonyl-hydroperoxide-derived peroxyhemiacetal (Yee et al., 2012). The temporal profiles of the $\mathrm{C}_{12} \mathrm{H}_{23} \mathrm{O}^{+}$ion under both high- and low- $\mathrm{NO}_{\mathrm{x}}$ conditions (Exp. 2 vs. Exp. 6) exhibit distinct growth patterns (Fig. 4). Under high- $\mathrm{NO}_{\mathrm{x}}$ conditions, the $\mathrm{C}_{12} \mathrm{H}_{23} \mathrm{O}^{+}$ion signal increases rapidly to a maximum during the first $2 \mathrm{~h}$ and decays over the next $\sim 14 \mathrm{~h}$. The temporal behavior of the $\mathrm{C}_{12} \mathrm{H}_{23} \mathrm{O}^{+}$ion is a result of its rapid formation, i.e., uptake of $\delta$-hydroxycarbonyl onto particles and subsequent cyclization, and relatively slower removal, i.e., dehydration. Under low- $\mathrm{NO}_{\mathrm{x}}$ conditions, the $\mathrm{C}_{12} \mathrm{H}_{23} \mathrm{O}^{+}$ion increases over the course of a $20 \mathrm{~h}$ experiment because of the accumulative formation of peroxyhemiacetal. During the first $3 \mathrm{~h}$ of irradiation under low- $\mathrm{NO}_{\mathrm{x}}$ conditions, the organic loading is below the AMS detection limit; thus the $\mathrm{C}_{12} \mathrm{H}_{23} \mathrm{O}^{+}$ion signal does not appear in Fig. 4 during this period. The $\mathrm{C}_{12} \mathrm{H}_{23} \mathrm{O}^{+}$ion signal under low- $\mathrm{NO}_{\mathrm{x}}$ conditions therefore potentially represents peroxyhemiacetal, since the formation of peroxides is the major reaction pathway in the $\mathrm{RO}_{2}+\mathrm{HO}_{2}$ dominant regime. This is again consistent with the mechanism prediction that the formation of alkyl-substituted dihydrofuran is unimportant under low- $\mathrm{NO}_{\mathrm{x}}$ conditions (Fig. 3b (L)).

Figure 5 shows temporal profiles of the ion $\mathrm{C}_{12} \mathrm{H}_{22} \mathrm{O} \cdot \mathrm{H}^{+}$ detected by CIMS and the ion $\mathrm{C}_{12} \mathrm{H}_{23} \mathrm{O}^{+}$detected by AMS 

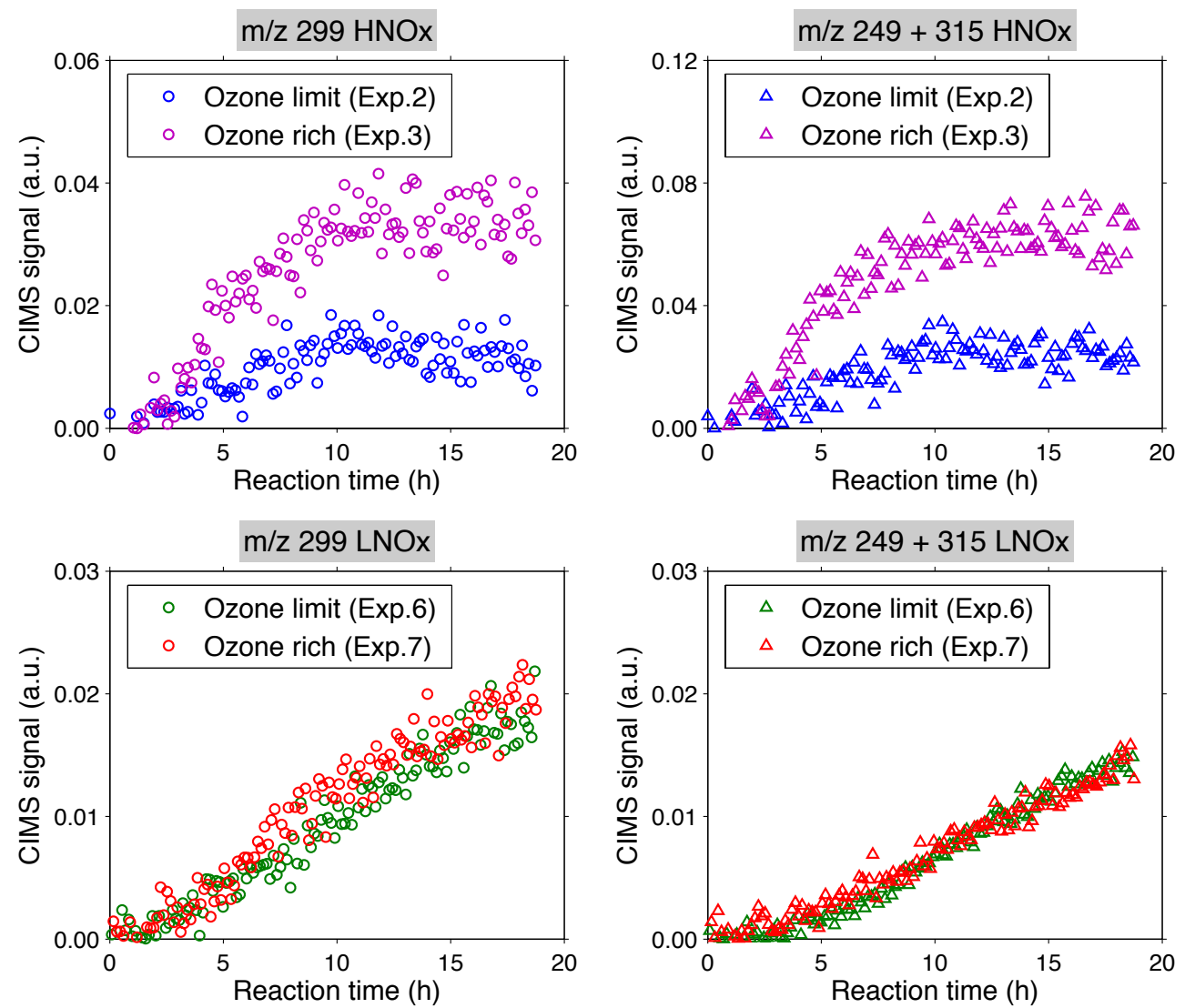

Fig. 6. Time-dependent evolution of CIMS measured signals at $m / z$ 299, and $m / z \quad 249$ and 315, as a function of $\mathrm{O}_{3}$ levels under high- and low- $\mathrm{NO}_{\mathrm{x}}$ conditions over the course of $20 \mathrm{~h}$ photooxidation.

in the presence of $\mathrm{NO}_{\mathrm{x}}$ under varying $\mathrm{RH}$. In general, the AMS ion $\mathrm{C}_{12} \mathrm{H}_{23} \mathrm{O}^{+}$peaks $\sim 3 \mathrm{~h}$ earlier than the CIMS ion $\mathrm{C}_{12} \mathrm{H}_{22} \mathrm{O} \cdot \mathrm{H}^{+}$. The decay rates of AMS ion $\mathrm{C}_{12} \mathrm{H}_{23} \mathrm{O}^{+}$, which is calculated by assuming first-order kinetics, are $4.02 \times 10^{-3}, 3.06 \times 10^{-3}, 1.71 \times 10^{-3}$, and $1.37 \times 10^{-3} \mathrm{~s}^{-1}$ at $\mathrm{RH}$ of $3,10,20$, and $50 \%$, respectively. Aerosol water content could slow down the formation and removal rate of AMS ion $\mathrm{C}_{12} \mathrm{H}_{23} \mathrm{O}^{+}$, mainly because (1) water could accelerate the hydration rate, thus changing the equilibrium coefficient of the interconversion between cyclic hemiacetal and dihydrofuran, and (2) the addition of water might neutralize the particle-phase acid (e.g., $\mathrm{HNO}_{3}$ ), which is thought to catalyze the cyclization of $\delta$-hydroxycarbonyl to cyclic hemiacetal (Lim and Ziemann, 2009c). The decay rates of AMS ion $\mathrm{C}_{12} \mathrm{H}_{23} \mathrm{O}^{+}$are within the same order of magnitude of that measured for 5-hydroxy-2-pentanone at 3\% RH, indicating that the dehydration of cyclic hemiacetal is the rate-limiting step in the overall heterogeneous conversion process. Water vapor influences CIMS sensitivity to certain compounds in negative mode by clustering with the reagent ion $\mathrm{CF}_{3} \mathrm{O}^{-}$ to form $\left[\mathrm{H}_{2} \mathrm{O} \cdot \mathrm{CF}_{3} \mathrm{O}\right]^{-}$. The decreasing intensity of the ion $\mathrm{C}_{12} \mathrm{H}_{22} \mathrm{O} \cdot \mathrm{H}^{+}$as $\mathrm{RH}$ increases is likely indicative of this effect.

\subsection{Products from alkyl-substituted dihydrofuran oxidation}

Products unique to the alkyl-substituted dihydrofuran oxidation chemistry have been proposed based on CIMS measured $m / z$ signals; see Table 2 for chemical structures. Authentic standards are not commercially available for these products. Compounds from the dodecane photooxidation route that share the same $m / z$ signal with alkyl-substituted dihydrofuran oxidation products are also presented in Table 2. The CIMS signal $(-) m / z 346$ is composed of $2-$ nitroxy-2-alkyl-3-hydroxyl-5-heptyl-tetrahydrofuran and 2carbonyl-5-hydroxyl-2-dodecyl-nitrate. The latter is a thirdgeneration product resulting from the further oxidation of dodecyl nitrate. The branching ratio for the addition of an $-\mathrm{ONO}_{2}$ group is much lower than that for the formation of the RO radical; therefore the interference of 2-carbonyl5-hydroxyl-2-dodetyl-nitrate in the $(-) m / z 346$ signal can be neglected. The CIMS signal $(-) m / z 299$ represents $3-$ propoxy-nonanal, which is a primary product from both $\mathrm{OH}$ oxidation and ozonolysis of alkyl-substituted dihydrofuran, and 8-hydroxy-3,5-dodecanedione, which is produced from the further oxidation of dodecyl nitrate. As discussed earlier, 
Table 2. Proposed structures for CIMS ions unique to the alkyl-substituted dihydrofuran chemistry. C and $\mathrm{T}$ indicate the cluster and transfer product, respectively. Commercial standards are not available.

\begin{tabular}{|c|c|c|c|c|c|}
\hline $\begin{array}{c}\text { Observed } \\
\mathrm{m} / \mathrm{z}\end{array}$ & Product & $\begin{array}{l}\text { Chemical } \\
\text { formula }\end{array}$ & $\begin{array}{l}\text { Proposed } \\
\text { structure }\end{array}$ & $\begin{array}{l}\text { Chemical } \\
\text { pathway }\end{array}$ & Interference \\
\hline $183(+)$ & $\mathrm{T}$ & $\mathrm{C}_{12} \mathrm{H}_{22} \mathrm{O}$ & & $\begin{array}{c}\text { Heterogeneous } \\
\text { conversion }\end{array}$ & $\mathrm{OH}$ \\
\hline $328(-)$ & $\mathrm{C}$ & $\mathrm{C}_{12} \mathrm{H}_{21} \mathrm{NO}_{4}$ & & $\begin{array}{c}\text { Heterogeneous } \\
\text { conversion }\end{array}$ & - \\
\hline $346(-)$ & $\mathrm{C}$ & $\mathrm{C}_{12} \mathrm{H}_{23} \mathrm{NO}_{5}$ & & OH-oxidation & $\mathrm{OH}$ \\
\hline $299(-)$ & $\mathrm{C}$ & $\mathrm{C}_{12} \mathrm{H}_{22} \mathrm{O}_{3}$ & & $\begin{array}{c}\text { OH-oxidation } \\
\text { Ozonolysis }\end{array}$ & $\mathrm{OH}$ \\
\hline $249(-)$ & $\mathrm{T}$ & $\mathrm{C}_{12} \mathrm{H}_{22} \mathrm{O}_{4}$ & & Ozonolysis & - \\
\hline $315(-)$ & $\mathrm{C}$ & $\mathrm{C}_{12} \mathrm{H}_{22} \mathrm{O}_{4}$ & & Ozonolysis & - \\
\hline $332(-)$ & $\mathrm{C}$ & $\mathrm{C}_{11} \mathrm{H}_{21} \mathrm{O}_{5} \mathrm{~N}$ & & Ozonolysis & - \\
\hline $348(-)$ & $\mathrm{C}$ & $\mathrm{C}_{11} \mathrm{H}_{21} \mathrm{O}_{6} \mathrm{~N}$ & & Ozonolysis & - \\
\hline $301(-)$ & $\mathrm{C}$ & $\mathrm{C}_{11} \mathrm{H}_{20} \mathrm{O}_{4}$ & & Ozonolysis & - \\
\hline
\end{tabular}

the formation and transformation of dodecyl nitrate is predicted to be a minor pathway, and thus the $(-) m / z 299$ is dominated by 3-propoxy-nonanal.

A distinct feature of proposed products from the dihydrofuran oxidation by either $\mathrm{OH}$ or $\mathrm{O}_{3}$ is the formation of an ester group $(-\mathrm{C}(\mathrm{O}) \mathrm{O}-)$ or an ether group $(-\mathrm{O}-)$, both of which cannot be accessed from photochemical reaction pathways initiated by the $\mathrm{OH}$ attack on the aliphatic hydrocar- bon. The $\mathrm{OH}$ oxidation channel leads solely to the formation of tetrahydrofuran and carbonyl ester. In the ozonolysis pathway, on the other hand, the reaction of stabilized Criegee intermediates with water produces one ester group containing aldehyde (3-propoxy-nonanal) and carboxylic acid (3propoxy-nonanic acid); see proposed structures in Table 2. From the intact $\mathrm{C}_{12}$ skeleton and highly oxygenated nature, these two products are consistent with CIMS signals in 

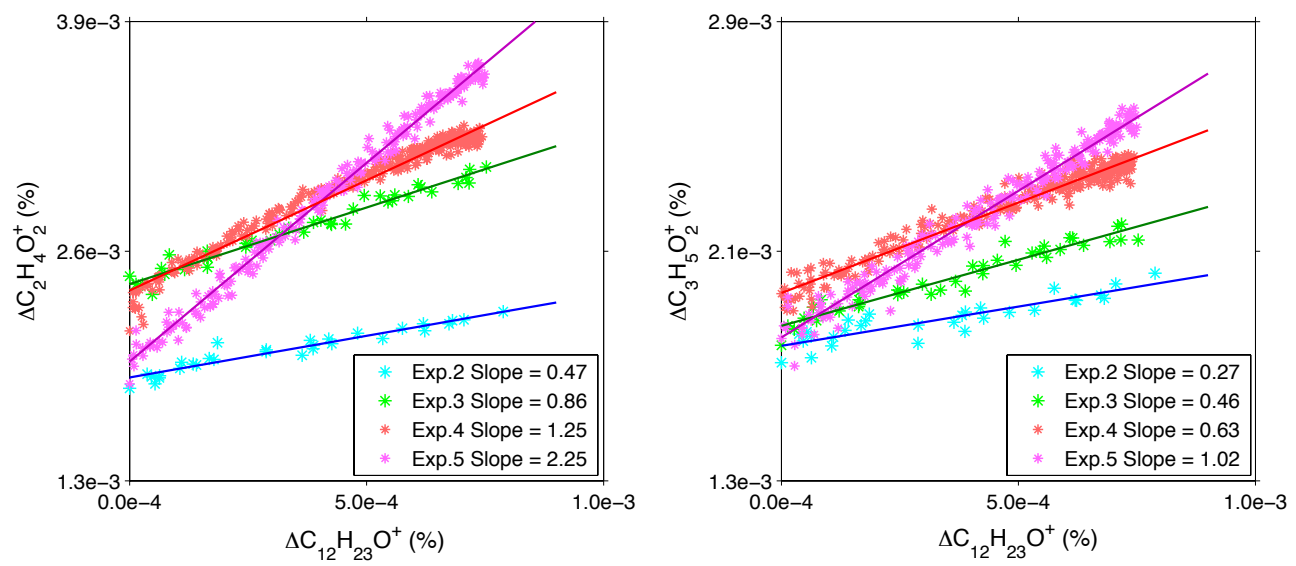

Fig. 7. Time-dependent evolution of AMS measured ion intensities of $\mathrm{C}_{2} \mathrm{H}_{4} \mathrm{O}_{2}^{+}$and $\mathrm{C}_{3} \mathrm{H}_{5} \mathrm{O}_{2}^{+}$as a function of decay of the $\mathrm{C}_{12} \mathrm{H}_{23} \mathrm{O}^{+}$ signal.

$(-) m / z 299$ and $(-) m / z 249$ and 315 in negative mode with little interference from other products.

Figure 6 shows the temporal profiles of $(-) m / z$ 299, as well as $(-) m / z 249$ and 315, under " $\mathrm{O}_{3}$-limiting" (Exp. 2) and "O ${ }_{3}$-rich" (Exp. 3) conditions. The decay rates of their precursor $(+) m / z 183$, as calculated by assuming first-order kinetics, are $1.19 \times 10^{-5} \mathrm{~s}^{-1}$ and $1.44 \times 10^{-5} \mathrm{~s}^{-1}$, respectively. Under $\mathrm{O}_{3}$-rich conditions, both species increase and eventually level off. When $\mathrm{O}_{3}$ reaction is less competitive, the CIMS signals start to decrease after $10 \mathrm{~h}$ of photooxidation. Note that these three ions were also detected under low$\mathrm{NO}_{\mathrm{x}}$ conditions. No significant increase in their signals was observed in the $\mathrm{O}_{3}$-rich environment (Exp. 7), compared with the $\mathrm{O}_{3}$-limiting case (Exp. 6). If they were assigned the same chemical structures as those proposed under high- $\mathrm{NO}_{\mathrm{x}}$ conditions, their growth pattern would suggest a minor formation of their precursor alkyl-substituted dihydrofuran. This can be attributed to the slowdown or even termination of the dehydration of cyclic hemiacetal in the absence of strong acid catalysis (Atkinson et al., 2008; Lim and Ziemann, 2009c).

\subsection{Ozonolysis vs. OH oxidation}

Carboxylic acids produce significant signals at $\mathrm{m} / \mathrm{z} 60$ and 73, specifically $\mathrm{C}_{2} \mathrm{H}_{4} \mathrm{O}_{2}^{+}$and $\mathrm{C}_{3} \mathrm{H}_{5} \mathrm{O}_{2}^{+}$, in the AMS measurement (Aiken et al., 2008). The formation of these two ions, as a function of the time-dependent decay of the ion $\mathrm{C}_{12} \mathrm{H}_{23} \mathrm{O}^{+}$, is shown under different $\mathrm{RH}$ conditions in Fig. 7. The largest slope of either $\Delta \mathrm{C}_{2} \mathrm{H}_{4} \mathrm{O}_{2}^{+} / \Delta \mathrm{C}_{12} \mathrm{H}_{23} \mathrm{O}^{+}$ or $\Delta \mathrm{C}_{3} \mathrm{H}_{5} \mathrm{O}_{2}^{+} / \Delta \mathrm{C}_{12} \mathrm{H}_{23} \mathrm{O}^{+}$is associated with the highest RH, i.e., $50 \%$. However, the production of $\mathrm{C}_{2} \mathrm{H}_{4} \mathrm{O}_{2}^{+}$and $\mathrm{C}_{3} \mathrm{H}_{5} \mathrm{O}_{2}^{+}$is not significant under dry conditions. Also, the changes in slopes along with changes in RH values are consistent for both ions. This indicates that the formation of the carboxylic acid functional group detected in particles is associated with the water vapor concentration in the gas phase, consistent with the reaction of the stabilized Criegee interme- diates with water in the substituted dihydrofuran oxidation system.

Two dominant oxygen-containing ions, $\mathrm{m} / \mathrm{z} 44$ (mostly $\left.\mathrm{CO}_{2}^{+}\right)$and $m / z 43\left(\mathrm{C}_{3} \mathrm{H}_{7}^{+}\right.$and $\left.\mathrm{C}_{2} \mathrm{H}_{3} \mathrm{O}^{+}\right)$, have been widely used to characterize organic aerosol evolution in chamber and field observations. Previous studies have shown that $\mathrm{CO}_{2}^{+}$results mostly from the thermal decarboxylation of an organic acid group (Alfarra, 2004). The $f_{44}$ (ratio of $m / z 44$, mostly $\mathrm{CO}_{2}^{+}$, to total signal in the component mass spectrum) axis is also considered to be an indicator of photochemical aging (Alfarra et al., 2004; Aiken et al., 2008; Kleinman et al., 2008). It has been found that increasing $\mathrm{OH}$ exposure increases $f_{44}$ and decreases $f_{43}$ (ratio of $m / z$ 43, mostly $\mathrm{C}_{2} \mathrm{H}_{3} \mathrm{O}^{+}$, to total signal in the component mass spectrum) for SOA generated from gas-phase alkanes (Lambe et al., 2011). The $\mathrm{C}_{2} \mathrm{H}_{3} \mathrm{O}^{+}$ion at $\mathrm{m} / z, 43$ is assumed predominantly due to nonacid oxygenates, such as saturated carbonyl groups ( $\mathrm{Ng}$ et al., 2011). The evolution of dodecane SOA from four experiments (Table 1), characterized by different $\mathrm{OH}$ and $\mathrm{O}_{3}$ exposure, and different $\mathrm{RH}$ levels, is shown in $f_{\mathrm{CO}_{2}+}-f_{\mathrm{C}_{2}} \mathrm{H}_{3} \mathrm{O}^{+}$space in Fig. 8. Overall, high- $\mathrm{NO}_{\mathrm{x}}$ dodecane SOA lies to the lower left of the triangular region derived for ambient SOA. The relatively high organic loading ( $200 \mathrm{ppb}$ dodecane) employed in this study favors partitioning of less oxidized species, which would remain in the gas phase under atmospheric conditions. For each experiment, $f_{\mathrm{CO}_{2}^{+}}$decreases and $f_{\mathrm{C}_{2} \mathrm{H}_{3} \mathrm{O}^{+}}$increases with increasing SOA at the beginning of irradiation. After several hours of photooxidation, the trends reverse, resulting in increasing $f_{\mathrm{CO}_{2}^{+}}$and decreasing $f_{\mathrm{C}_{2} \mathrm{H}_{3} \mathrm{O}^{+}}$. Curvature in $f_{\mathrm{CO}_{2}^{+}}-f_{\mathrm{C}_{2} \mathrm{H}_{3} \mathrm{O}^{+}}$ space has been also observed in other chamber/flow reactor studies (Kroll et al., 2009; Ng et al., 2010; Chhabra et al., 2011; Lee et al., 2011; Lambe et al., 2011). When the organic loading is small, only the highly oxygenated and least volatile species partition to the particle phase. As particles grow, more volatile and less oxidized species are able to 

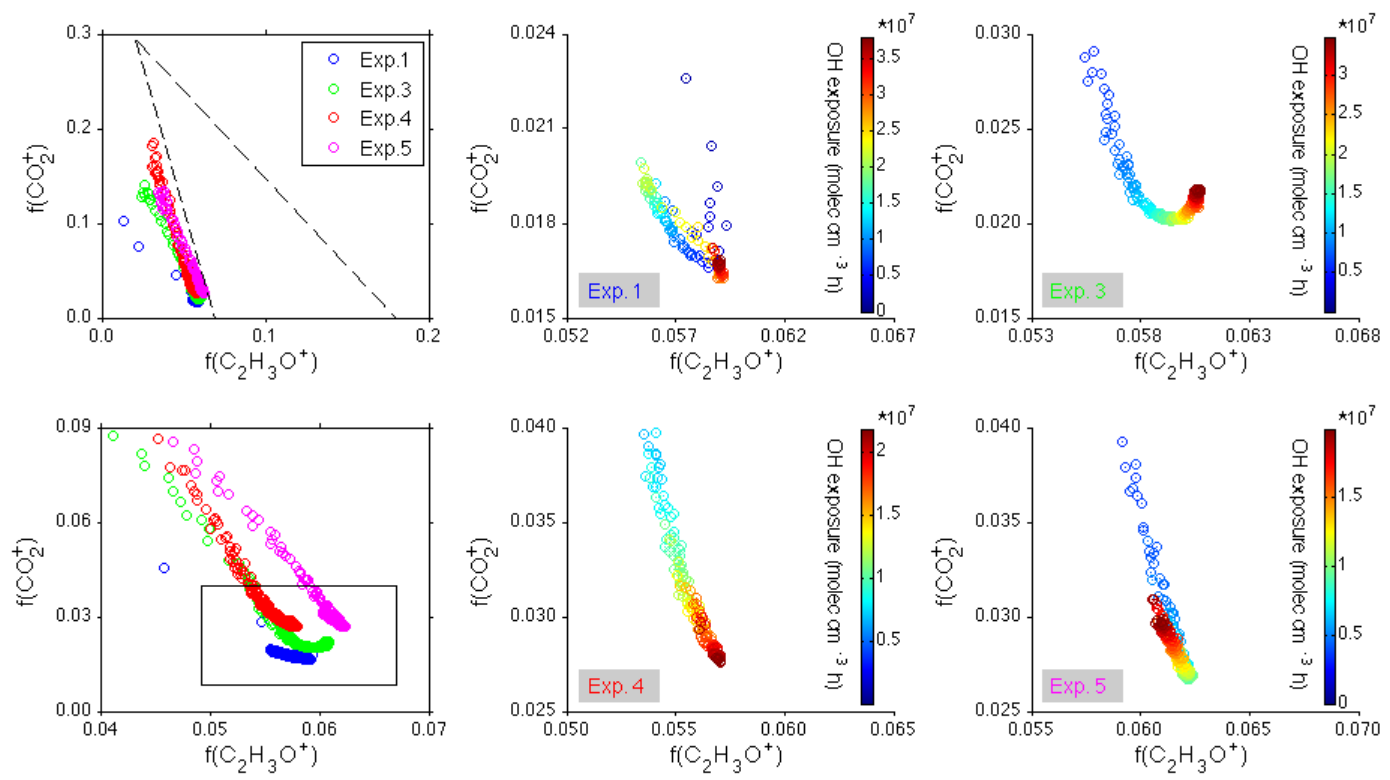

Fig. 8. SOA evolution as a function of $\mathrm{OH}$ exposure vs. $\mathrm{O}_{3}$ exposure from dodecane photochemistry under high-NO $\mathrm{O}_{\mathrm{x}}$ conditions in the $f_{44}$ vs. $f_{43}$ space. The top-left graph shows the combination of all the data, and the bottom-left graph shows an expanded version. The other graphs show the specific behavior of each experiment: Exp. 1 corresponds to a regime in which $\mathrm{OH}$ oxidation of dihydrofuran is dominant. Exp. 3, 4, and 5 correspond to a regime in which ozonolysis of dihydrofuran is dominant, at 10, 20, and $50 \%$ RH, respectively.
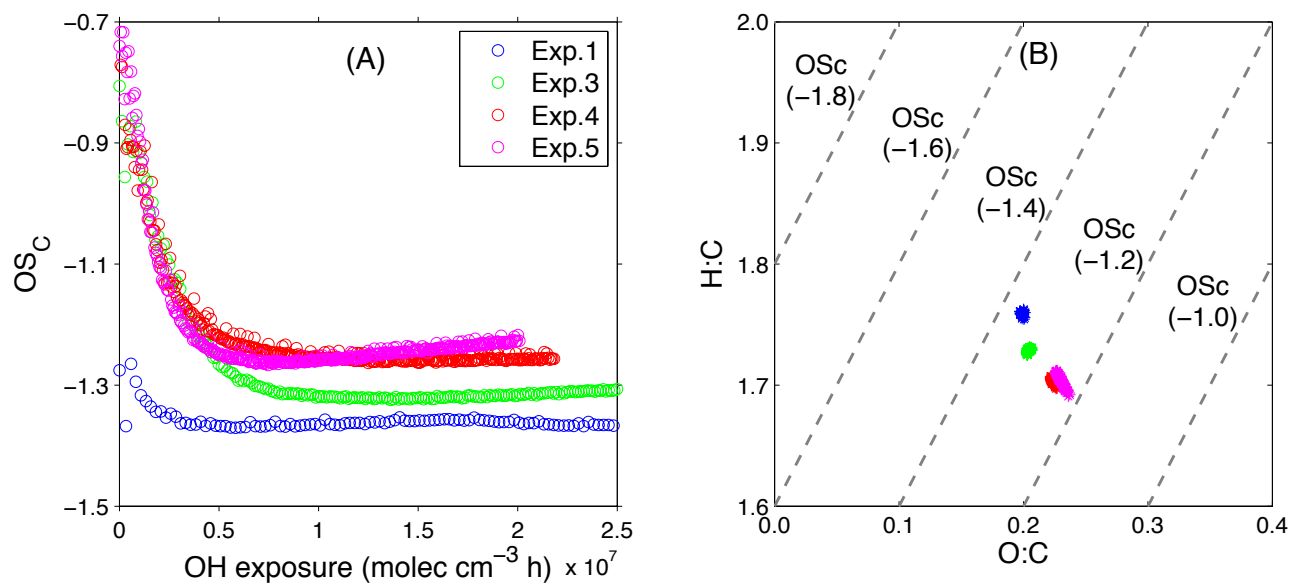

Fig. 9. (A) SOA average carbon oxidation state as a function of $\mathrm{OH}$ exposure from dodecane photochemistry under high- $\mathrm{NO}_{\mathrm{x}}$ conditions. Exp. 1 corresponds to a regime in which $\mathrm{OH}$ oxidation of dihydrofuran is dominant. Exp. 3, 4, and 5 correspond to a regime in which ozonolysis of dihydrofuran is dominant, at 10, 20, and 50\% RH, respectively. (B) van Krevelen diagram. AMS measured O : C vs. H: C ratios for the four experiments under the $\mathrm{OH}$ total exposure ranging from $1.0 \times 10^{7}$ to $2.0 \times 10^{7}$ molecules $\mathrm{cm}^{-3} \mathrm{~h}$. Gray dashed lines denote the average carbon oxidation state.

participate in equilibrium partitioning, leading to a decrease in $f_{\mathrm{CO}_{2}^{+}}$. Progressive oxidation of semivolatile products in the gas phase eventually leads to multifunctionalized species contributing to the increase of $f_{\mathrm{CO}_{2}^{+}}$.

Both $\mathrm{O}_{3}$ - and $\mathrm{OH}$-initiated oxidation of substituted dihydrofuran lead to the formation of $f_{\mathrm{CO}_{2}^{+}}$, via the thermal decarboxylation of an organic acid group and photochemical aging, respectively. The contribution of each reaction path- way to the intensity of $f_{\mathrm{CO}_{2}^{+}}$can be evaluated based on the $f_{\mathrm{CO}_{2}^{+}}-f_{\mathrm{C}_{2} \mathrm{H}_{3} \mathrm{O}^{+}}$plot. As discussed in Sect. 2.1, Exp. 1 is designed as an $\mathrm{OH}$-dominant case, in which it is estimated that $>73 \%$ of the dihydrofuran reacts with $\mathrm{OH}$ over the course of the experiment. Exp. 3, 4, and 5 were designed to be $\mathrm{O}_{3}$-dominant at $10 \%, 20 \%$, and $50 \% \mathrm{RH}$, respectively. Approximately 96, 97, and $98 \%$ of substituted dihydrofuran is predicted to react with $\mathrm{O}_{3}$ when it peaks after $\sim 3 \mathrm{~h}$ of photooxidation in Exp. 3, 4, and 5, respectively. 

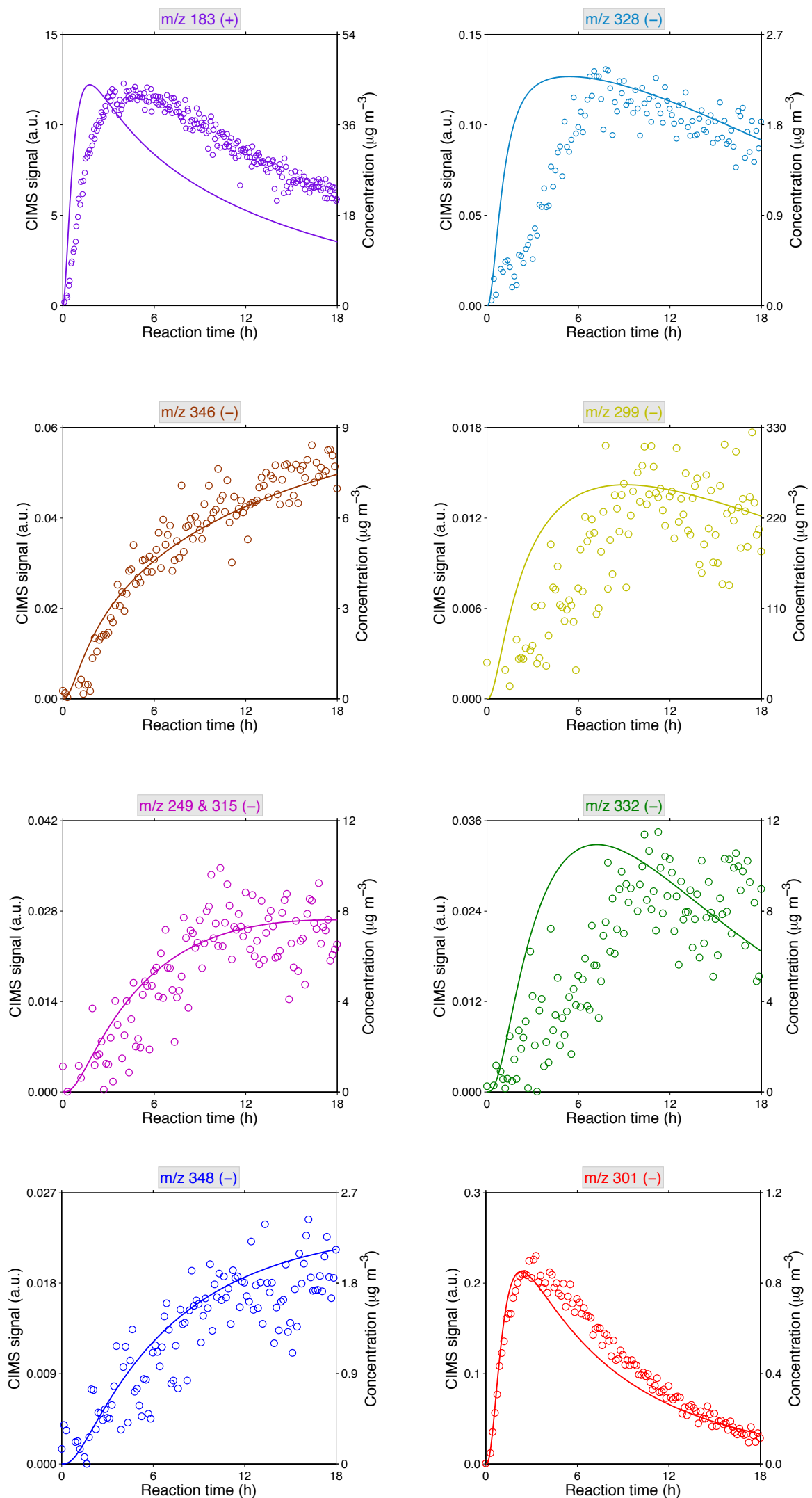

Fig. 10. Comparison of CIMS measured ions in positive and negative mode, with chemical structures proposed in Table 2, with model simulations using experimental conditions of Exp. 2. 


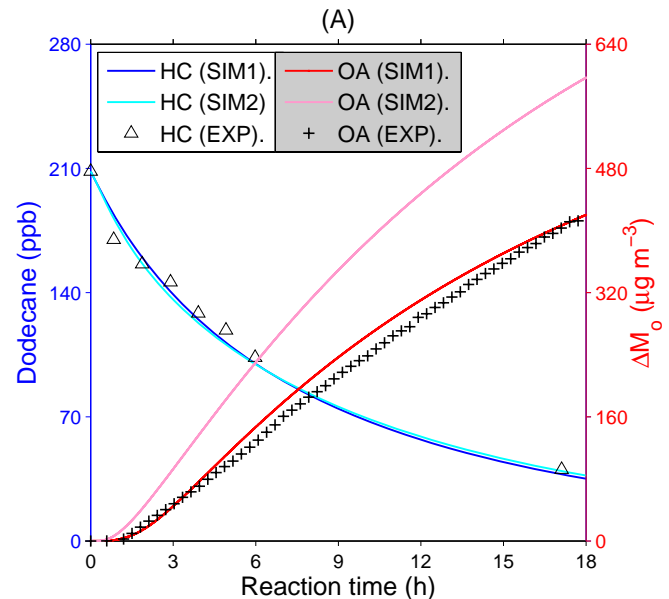

(C)

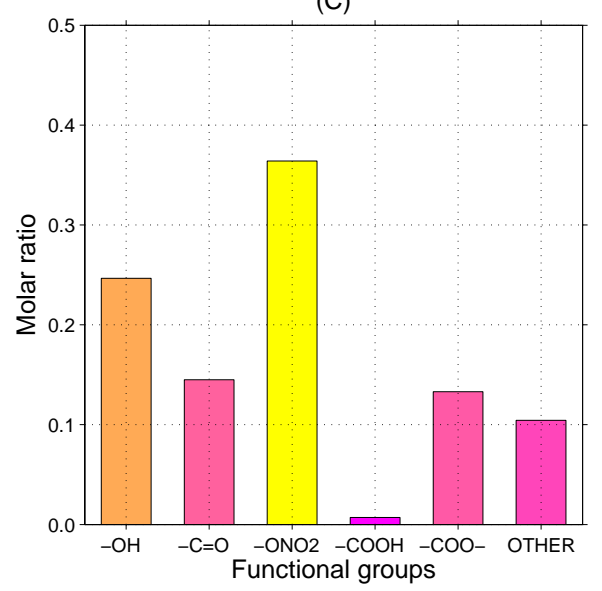

(B)

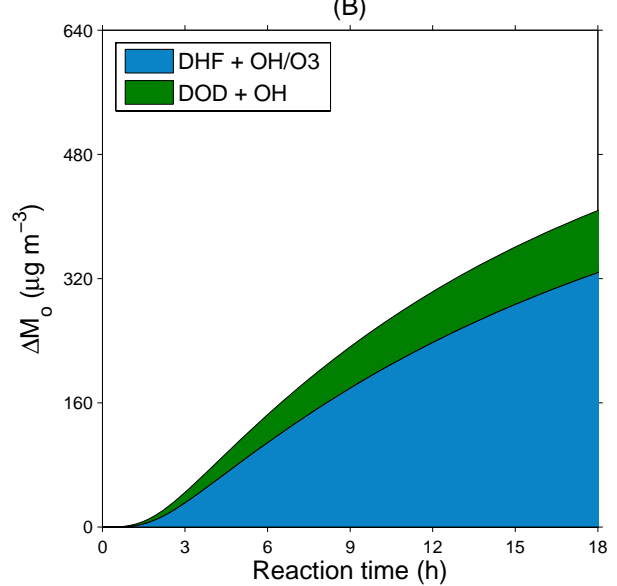

(D)

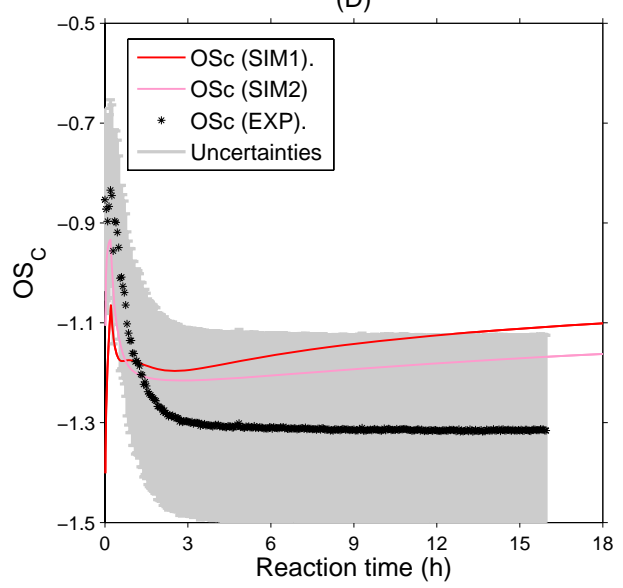

Fig. 11. (A) Comparison of the predicted dodecane decay and SOA growth with observations (Exp. 2). SIM1 represents the full mechanism simulations under initial conditions of Exp. 2. SIM2 is the simulations in the absence of the substituted dihydrofuran formation channel. (B) The contribution of dihydrofuran chemistry $\left(\mathrm{DHF}+\mathrm{OH} / \mathrm{O}_{3}\right)$ vs. dodecane photochemistry (DOD+OH) to the total organic mass. (C) Molar fractions of major functional groups after $3 \mathrm{~h}$ of photochemical reaction (when alkyl-substituted dihydrofuran peaks and organic loading is $\sim 50 \mu \mathrm{g} \mathrm{m}^{-3}$ ) as predicted by SIM1. Note that "other" includes dihydrofuran, tetrahydrofuran, and ether moieties. (D) Comparison of the predicted average carbon oxidation state with observations (Exp. 2).

As shown in Fig. 8, the intensities of $f_{\mathrm{CO}_{2}^{+}}$in Exp. 1, 3, 4 , and 5 are $0.019,0.020,0.028$, and 0.030 , respectively, at the same $\mathrm{OH}$ exposure, i.e., $2 \times 10^{7}$ molecules $\mathrm{cm}^{-3} \mathrm{~h}$. The increase in $f_{\mathrm{CO}_{2}^{+}}$intensities results from the increasing $\mathrm{O}_{3}$ and RH levels in these four experiments. Overall, Exp. 1 exhibits the least intensity of $f_{\mathrm{CO}_{2}^{+}}$at the end of the experiment, i.e., 0.017 , although the total $\mathrm{OH}$ exposure is the highest, i.e., $3.8 \times 10^{7}$ molecules $\mathrm{cm}^{-3} \mathrm{~h}$. The total $\mathrm{OH}$ exposures for Exp. 3, 4, and 5 are $3.5 \times 10^{7}, 2.2 \times 10^{7}$, and $2.1 \times 10^{7}$ molecules $\mathrm{cm}^{-3} \mathrm{~h}$, respectively, which are less than that in Exp. 1. However, the intensities of $f_{\mathrm{CO}_{2}^{+}}$for these three experiments are 35-82\% higher than that in Exp. 1 at the end of experiments. In addition, the intensity of $f_{\mathrm{CO}_{2}^{+}}$increases along with increasing $\mathrm{RH}$ and $\mathrm{O}_{3}$ exposure for these three experiments, varying from 0.023 to 0.031 . The highest $f_{\mathrm{CO}_{2}^{+}}$intensity shown in Exp. 5 corresponds to the highest $\mathrm{O}_{3}$ exposure and $\mathrm{RH}$ level, but lowest $\mathrm{OH}$ exposure.
The difference in elemental composition of organic particles produced from $\mathrm{O}_{3}$-dominant vs. $\mathrm{OH}$-dominant environments is also examined via the AMS measured $\mathrm{O}: \mathrm{C}$ and $\mathrm{H}: \mathrm{C}$ ratios in the van Krevelen plot and the timedependent evolution of the average carbon oxidation state $\left(\mathrm{OS}_{C}=2 \times \mathrm{O}: \mathrm{C}-\mathrm{H}: \mathrm{C}\right)$; see Fig. 9. In general, the $\mathrm{OS}_{C}$ values calculated fall into a region characterized by oxidized primary organic aerosol and semivolatile oxidized organic aerosol (Kroll et al., 2011). The measured O : C ( 0.2) and $\mathrm{H}: \mathrm{C}(\sim 1.7)$ ratios at an $\mathrm{OH}$ exposure on the order of $\sim 10^{7}$ molecules $\mathrm{cm}^{-3} \mathrm{~h}$ agree with those measured for organic aerosols generated from $\mathrm{C}_{10}-\mathrm{C}_{17}$ alkanes (Lambe et al., 2011, 2012). As mentioned earlier, the four experiments (Exp. 1, 3, 4, and 5) were conducted in such a way that the total $\mathrm{OH}$ exposure is decreasing, whereas the total $\mathrm{O}_{3}$ and $\mathrm{RH}$ exposure is increasing along with increasing experimental numbers (for example, Exp. 5 has the least 


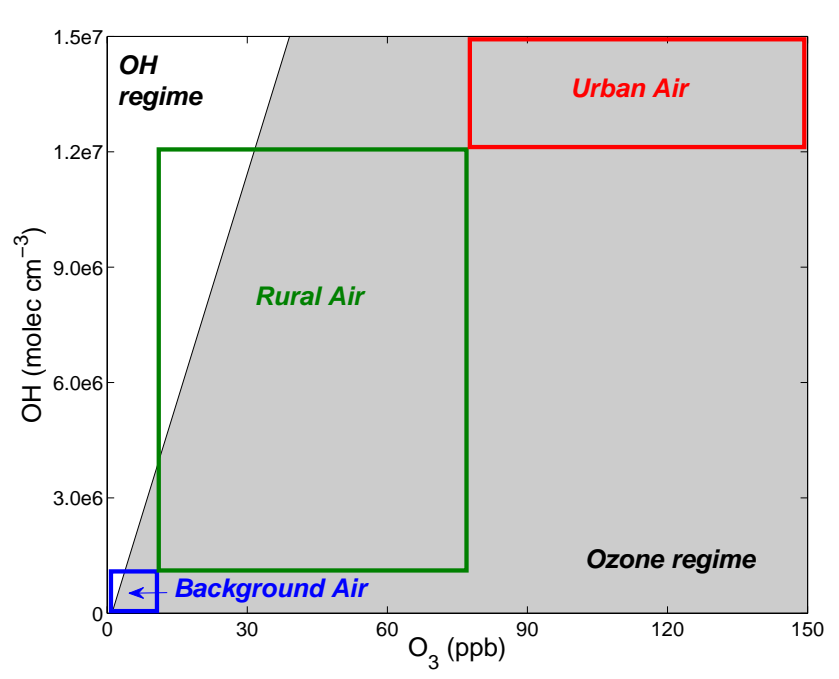

Fig. 12. Regimes of dominance of ozonolysis vs. OH oxidation of substituted dihydrofuran. Daily maximum $\mathrm{OH}$ concentrations vary by regions in the troposphere, i.e., $10^{5}-10^{6}$ molecules $\mathrm{cm}^{-3}$ for background air, $10^{6}-10^{7}$ molecules $\mathrm{cm}^{-3}$ for rural air, and $>10^{7}$ molecules $\mathrm{cm}^{-3}$ for urban air, with a global average concentration of $1 \times 10^{6}$ molecules $\mathrm{cm}^{-3}$. Daily average surface ozone mixing ratios in rural areas are between 10 and $50 \mathrm{ppb}$, but these can exceed $100 \mathrm{ppb}$ in polluted urban areas.

$\mathrm{OH}$ exposure but the largest $\mathrm{O}_{3}$ and $\mathrm{RH}$ exposure). A clear trend observed from the van Krevelen plot is that $\mathrm{O}: \mathrm{C}$ increases, whereas $\mathrm{H}: \mathrm{C}$ decreases under elevated $\mathrm{O}_{3}$ and RH levels. The effect of ozonolysis of substituted dihydrofuran chemistry on the aerosol chemical composition can be evaluated by comparing $\mathrm{OS}_{C}(\mathrm{O}: \mathrm{C}$ vs. $\mathrm{H}: \mathrm{C})$ for these four experiments under the same $\mathrm{OH}$ exposure. Consistent with our findings in $f_{\mathrm{CO}_{2}^{+}}-f_{\mathrm{C}_{2} \mathrm{H}_{3} \mathrm{O}^{+}}$space, the highest $\mathrm{OS}_{C}$ is observed under the highest $\mathrm{O}_{3}$ exposure and $\mathrm{RH}$ level, but lowest $\mathrm{OH}$ exposure $(98 \%$ substituted dihydrofuran reacts with $\mathrm{O}_{3}$ at $55 \% \mathrm{RH}$ ). With the same $\mathrm{OH}$ exposure, e.g., $1.5 \times 10^{7}$ molecules $\mathrm{cm}^{-3} \mathrm{~h}$, the average carbon oxidation state increases from -1.36 in $\mathrm{O}_{3}$-limiting environments (Exp. 1) to -1.25 in $\mathrm{O}_{3}$-dominant environments (Exp. 5). In conclusion, ozonolysis of substituted dihydrofuran plays an important role in the formation of highly oxidized aerosol in alkane SOA.

\subsection{Experiment and model comparison}

Figure 10 shows the temporal profiles of CIMS measured ions in $(+/-)$ mode, with structures proposed in Table 2, together with the corresponding model predictions under conditions of Exp. 2. In general, four time-dependent growth patterns are observed in experiments, which are also captured by model predictions. "Pattern 1" denotes species with rapid removal pathways, e.g., $m / z 301(-)$, with a proposed structure of $\delta$-hydroxycarbonyl. In the current mechanism, the overall heterogeneous conversion rate of $\delta$-hydroxycarbonyl to substituted dihydrofuran is taken as $3 \times 10^{-3} \mathrm{~s}^{-1}$. The model output is consistent with the observed time-dependent trend when this rate is used. Up to $\sim 90 \%$ of $\mathrm{m} / z 301$ (-) is consumed due to this rapid heterogeneous reaction pathway at $3 \% \mathrm{RH}$ after $18 \mathrm{~h}$ of photooxidation. "Pattern 2" is indicative of a species that also reacts rapidly, but with a much slower consumption rate than species of pattern 1. A typical example here is $m / z 183(+)$, which represents the alkyl-substituted dihydrofuran. The reaction rate constants of alkyl-substituted dihydrofuran with either $\mathrm{OH}$ or $\mathrm{O}_{3}$ are at least an order of magnitude higher than the generic reaction rate constant for the $\mathrm{OH}$ abstraction reaction, which is the dominant gas-phase pathway in the dodecane photooxidation mechanism. The simulated peak occurs $\sim 2 \mathrm{~h}$ earlier than observations, indicating that the formation rate of alkylsubstituted dihydrofuran might be slower than the decay rate of its precursor, $\delta$-hydroxycarbonyl, considering that fact that the acid-catalyzed dehydration process in the particle phase is the rate-limiting step. The extent to which the formation rate is slower than the decay rate, however, is unknown since the measurement of rate constants for individual steps is infeasible in this study. "Pattern 3" reflects the temporal profiles for a majority of ions here, e.g., $m / z$ 328(-), 299(-), $249(-), 315(-)$, and 332(-). Compounds proposed for the above $\mathrm{m} / \mathrm{z}$ can be categorized as semivolatile products. In the gas phase, they undergo functionalization or fragmentation, or partition into the particle phase as the precursors of SOA. Overall, the temporal profiles of species in pattern 3 are governed by the progressive photochemistry in the gas phase and gas-particle equilibrium partitioning. "Pattern 4", including $m / z 346(-)$ and $328(-)$ here, represents "nonvolatile" species. Owing to their low volatilities, they will immediately partition to the particle phase once formed and the gas-phase photooxidation becomes negligible, although it might still occur via the $\mathrm{OH}$ attack on $\mathrm{C}$ atoms.

Figure 11a shows the simulated SOA growth (SIM.1) using the initial conditions in Exp. 2, together with the observed total organic aerosol mass as a function of reaction time and $\mathrm{OH}$ exposure. The model reproduces the chamber measured SOA yield at $3 \% \mathrm{RH}$ when the conversion rate of $3 \times 10^{-3} \mathrm{~s}^{-1}$ is employed to represent the heterogeneous conversion of $\delta$-hydroxycarbonyl to dihydrofuran. A second simulation (SIM.2) was run with the complete dihydrofuran chemistry removed while other parameters were held constant. The total organic mass is $\sim 42 \%$ higher as a result after $18 \mathrm{~h}$ of photooxidation. The formation of alkylsubstituted dihydrofuran from $\delta$-hydroxycarbonyl is accompanied by an increase of vapor pressure from $5.36 \times 10^{-7}$ to $1.08 \times 10^{-4} \mathrm{~atm}$ at $300 \mathrm{~K}$, as predicted by SIMPOL.1, and the total organic mass formed decreases. Although the addition of $\mathrm{OH}$ to the $\mathrm{C}=\mathrm{C}$ double bond in the substituted dihydrofuran introduces an extra $\mathrm{OH}$ group, the decrease of vapor pressure owing to the addition of one $\mathrm{OH}$ group does not compensate for the heterogeneous conversion of both $-\mathrm{C}=\mathrm{O}$ and $-\mathrm{OH}$ groups in $\delta$-hydroxycarbonyl to an $-\mathrm{O}-$ group in 
a nonaromatic ring in dihydrofuran. The predicted average carbon oxidation state is $\sim 7-15 \%$ higher than observations. The overprediction is within the uncertainties in the $\mathrm{O}: \mathrm{C}$ $(31 \%)$ and $\mathrm{H}: \mathrm{C}(10 \%)$ measurement by AMS (Aiken et al., 2008). Incorporation of the substituted dihydrofuran formation and removal pathways in the model leads to an increase in the simulated $\mathrm{OS}_{C}$. Compared with compounds produced from dodecane photooxidation under high- $\mathrm{NO}_{\mathrm{x}}$ conditions, products from dihydrofuran chemistry tend to have a higher $\mathrm{O}: \mathrm{C}$ but lower $\mathrm{H}: \mathrm{C}$ due to the formation of ether, ester, and carboxylic acid functional groups. As a result, the calculated average carbon oxidation state is higher in the presence of chemical reactions that accelerate the aerosol aging process.

\section{Atmospheric implications}

The importance of ozone in the SOA formation from the photooxidation of long-chain alkanes under atmospherically relevant conditions depends on two factors: (1) the relative concentration of $\mathrm{O}_{3}$ vs. $\mathrm{OH}$, and (2) the heterogeneous conversion rate of $\delta$-hydroxycarbonyls to substituted dihydrofurans. Figure 12 shows regimes of ozonolysis vs. $\mathrm{OH}$ oxidation of substituted dihydrofuran corresponding to ranges of $\mathrm{OH}$ and $\mathrm{O}_{3}$ concentrations. The $\mathrm{OH}$-initiated oxidation of substituted dihydrofuran is predicted to dominate only under remote atmospheric conditions. Most alkane emissions occur in areas where ozone levels exceed $10 \mathrm{ppb}$, where the ozonolysis of dihydrofuran should be dominant.

Under conditions of the current study, the substituted dihydrofuran chemistry is predicted to account for $>95 \%$ of the removal pathways of $\delta$-hydroxycarbonyl (Fig. 1d (H)) and up to $\sim 80 \%$ of the total organic mass formed from dodecane photooxidation (Fig. 11b). This estimate sets the upper limit in terms of the contribution of substituted dihydrofuran chemistry to alkane SOA production in the actual atmosphere, where the RH is higher (50\% vs. $3 \%$ ), the ambient aerosols are less acidic, and the organic aerosol masses are lower $\left(\sim 10 \mu \mathrm{g} \mathrm{m}^{-3}\right)$ than in the chamber experiments ( $\sim 50 \mu \mathrm{g} \mathrm{m}^{-3}$ after $3 \mathrm{~h}$ of irradiation). Experimental evidence in this study shows that the heterogeneous conversion still occurs at $50 \%$ RH, but with less efficiency (Fig. 3). The water vapor abundance at $50 \% \mathrm{RH}$, however, compensates for the production of the less substituted dihydrofuran, leading to an eventually higher yield of carboxylic acids (Sect. 4.4). If the conversion of $\delta$-hydroxycarbonyl to substituted dihydrofuran occurs efficiently in the atmosphere, this could be a source of carboxylic acid in the ambient aerosols. It has been suggested that the heterogeneous formation of substituted dihydrofuran is acid-catalyzed (Atkinson et al., 2008; Lim and Ziemann, 2009a, b, c). Aerosols generated in the chamber environment in the presence of $\mathrm{NO}_{\mathrm{x}}$ are expected to be highly acidic due to the formation of $\mathrm{HNO}_{3}$. In the atmosphere, where ambient particles are less acidic or even neu- tralized, the heterogeneous conversion of $\delta$-hydroxycarbonyl to substituted dihydrofuran might be a minor process.

In summary, two impacts of substituted dihydrofuran chemistry on alkane SOA formation are expected. First, the SOA yield from the photooxidation of long-chain alkanes can be overpredicted without accounting for substituted dihydrofuran formation and removal pathways. Second, a substantial amount of carboxylic acid, ester, and tetrahydrofuran moieties can be produced, leading to higher $\mathrm{O}: \mathrm{C}$ but much lower $\mathrm{H}$ : $\mathrm{C}$ ratios, and thus a higher oxidation state of alkane SOA in general. In this manner, the dihydrofuran chemistry can be considered as a "dehydration" channel in alkane SOA formation.

\section{Supplementary material related to this article is available online at http://www.atmos-chem-phys.net/14/ 1733/2014/acp-14-1733-2014-supplement.pdf.}

Acknowledgements. This work was supported by National Science Foundation grant AGS-1057183.

Edited by: A. Laskin

\section{References}

Aiken, A. C., DeCarlo, P. F., and Jimenez, J. L.: Elemental analysis of organic species with electron ionization highresolution mass spectrometry, Anal. Chem., 79, 8350-8358, doi:10.1021/ac071150w, 2007.

Aiken, A. C., Decarlo, P. F., Kroll, J. H., Worsnop, D. R., Huffman, J. A., Docherty, K. S., Ulbrich, I. M., Mohr, C., Kimmel, J. R., Sueper, D., Sun, Y., Zhang, Q., Trimborn, A., Northway, M., Ziemann, P. J., Canagaratna, M. R., Onasch, T. B., Alfarra, M. R., Prevot, A. S. H., Dommen, J., Duplissy, J., Metzger, A., Baltensperger, U., and Jimenez, J. L.: O/C and OM,OC ratios of primary, secondary, and ambient organic aerosols with high-resolution time-of-flight aerosol mass spectrometry, Environ. Sci. Technol., 42, 4478-4485, 2008.

Alfarra, M. R., Coe, H., Allan, J. D., Bower, K. N., Boudries, H., Canagaratna, M. R., Jimenez, J. L., Jayne, J. T., Garforth, A. A., Li, S. M., and Worsnop, D. R.: Characterization of urban and rural organic particulate in the lower Fraser valley using two Aerodyne aerosol mass spectrometers, Atmos. Environ., 38, 57455758, 2004.

Arey, J., Aschmann, S. M., Kwok, E. S. C., and Atkinson, R.: Alkyl nitrate, hydroxyalkyl nitrate, and hydroxycarbonyl formation from the $\mathrm{NO}_{\mathrm{x}}$-air photooxidations of $\mathrm{C}_{5}-\mathrm{C}_{8}$ n-alkanes, J. Phys. Chem. A., 105, 1020-1027, 2001

Atkinson, R., Arey, J., and Aschmann, S. M.: Atmospheric chemistry of alkanes: Review and recent developments, Atmos. Environ., 42, 5859-5871, 2008.

Aumont, B., Valorso, R., Mouchel-Vallon, C., Camredon, M., LeeTaylor, J., and Madronich, S.: Modeling SOA formation from the oxidation of intermediate volatility n-alkanes, Atmos. Chem. Phys., 12, 7577-7589, doi:10.5194/acp-12-7577-2012, 2012. 
Aumont, B., Camredon, M., Mouchel-Vallon, C., La, S., Ouzebidour, F., Valorso, R., Lee-Taylor, J., and Madronich, S.: Modeling the influence of alkane molecular structure on secondary organic aerosol formation, Faraday Discuss., 165, 1-16, 2013.

Bloss, C., Wagner, V., Jenkin, M. E., Volkamer, R., Bloss, W. J., Lee, J. D., Heard, D. E., Wirtz, K., Martín-Reviejo, M., Rea, G., Wenger, J. C., and Pilling, M. J.: Development of a detailed chemical mechanism (MCMv3.1) for the atmospheric oxidation of aromatic hydrocarbons, Atmos. Chem. Phys., 5, 641-664, doi:10.5194/acp-5-641-2005, 2005.

Canagaratna, M. R., Jayne, J. T., Jimenez, J. L., Allan, J. D., Alfarra, M. R., Zhang, Q., Onasch, T. B., Drewnick, F., Coe, H., Middlebrook, A., Delia, A., Williams, L. R., Trimborn, A. M., Northway, M. J., DeCarlo, P. F., Kolb, C. E., Davidovits, P., and Worsnop, D. R.: Chemical and microphysical characterization of ambient aerosols with the Aerodyne aerosol mass spectrometer, Mass Spectrom. Rev., 26, 185-222, 2007.

Cappa, C. D., Zhang, X., Loza, C. L., Craven, J. S., Yee, L. D., and Seinfeld, J. H.: Application of the Statistical Oxidation Model (SOM) to Secondary Organic Aerosol formation from photooxidation of C12 alkanes, Atmos. Chem. Phys., 13, 1591-1606, doi:10.5194/acp-13-1591-2013, 2013.

Cavalli, F., Barnes, I., and Becker, K. H.: FTIR kinetic, product, and modeling study of the $\mathrm{OH}$-initiated oxidation of 1-butanol in air, Environ. Sci. Technol., 36, 1263-1270, 2000.

Chhabra, P. S., Ng, N. L., Canagaratna, M. R., Corrigan, A. L., Russell, L. M., Worsnop, D. R., Flagan, R. C., and Seinfeld, J. H.: Elemental composition and oxidation of chamber organic aerosol, Atmos. Chem. Phys., 11, 8827-8845, doi:10.5194/acp-11-88272011, 2011.

Craven, J. S., Yee, L. D., Ng, N. L., Canagaratna, M. R., Loza, C. L., Schilling, K. A., Yatavelli, R. L. N., Thornton, J. A., Ziemann, P. J., Flagan, R. C., and Seinfeld, J. H.: Analysis of secondary organic aerosol formation and aging using positive matrix factorization of high-resolution aerosol mass spectra: application to the dodecane low-NOx system, Atmos. Chem. Phys., 12, 1179511817, doi:10.5194/acp-12-11795-2012, 2012.

Crounse, J. D., McKinney, K. A., Kwan, A. J., and Wennberg, P. O.: Measurement of gas-phase hydroperoxides by chemical ionization mass spectrometry, Anal. Chem., 78, 6726-6732, 2006.

DeCarlo, P. F., Kimmel, J. R., Trimborn, A., Northway, M. J., Jayne, J. T., Aiken, A. C., Gonin, M., Fuhrer, K., Horvath, T., Docherty, K. S., Worsnop, D. R., and Jimenez, J. L.: Field-deployable, high-resolution, time-of-flight aerosol mass spectrometer, Anal. Chem., 78, 8281-8289, 2006.

Fraser, M. P., Cass, G. R., Simoneit, B. R. T., Rasmussen, R. A.: Air quality model evaluation data for organics. $4 . \mathrm{C}_{2}-\mathrm{C}_{36}$ nonaromatic hydrocarbons, Environ. Sci. Technol., 31, 2356-2367, 1997.

Gentner, D. R., Isaacman, G., Worton, D. R., Chan, A. W. H., Dallmann, T. R., Davis, L., Liu, S., Day, D. A., Russell, L. M., Wilson, K. R., Weber, R., Guha, A., Harley, R. A., and Goldstein, A. H.: Elucidating secondary organic aerosol from diesel and gasoline vehicles through detailed characterization of organic carbon emissions, P. Natl. Acad. Sci. USA, 109, 18318-18323, 2012.

Gong, H. M., Matsunaga, A., and Ziemann, P. J.: Products and mechanism of secondary organic aerosol formation from reactions of linear alkenes with $\mathrm{NO}_{3}$ radicals, J. Phys. Chem. A., 109, 4312-4324, 2005.
Hoekman, S. K.: Speciated measurements and calculated reactivities of vehicle exhaust emissions from conventional and reformulated gasolines, Environ. Sci. Technol., 26, 1206-1216, 1992.

Holt, T., Atkinson, R., and Arey, J.: Effect of water vapor concentration on the conversion of a series of 1,4-dydroxycarbonyls to dihydrofurans, J. Photochem. Photobiol. A: Chem., 176, 231-237, 2005.

Jathar, S. H., Miracolo, M. A., Tkacik, D. S., Donahue, N. M., Adams, P. J., and Robinson, A. L.: Secondary Organic Aerosol Formation from Photo-Oxidation of Unburned Fuel: Experimental Results and Implications for Aerosol Formation from Combustion Emissions, Environ. Sci. Technol., 47, 12886-12893, 2013.

Jenkin, M. E., Shallcross, D. E., Harvey, J. H.: Development and application of a possible mechanism for the generation of cis-pinic acid from the ozonolysis of $\alpha$ - and $\beta$-pinene, Atmos. Environ., 34, 2837-2850, 2000.

Jenkin, M. E., Saunders, S. M., Wagner, V., and Pilling, M. J.: Protocol for the development of the Master Chemical Mechanism, MCM v3 (Part B): tropospheric degradation of aromatic volatile organic compounds, Atmos. Chem. Phys., 3, 181-193, 2003, http://www.atmos-chem-phys.net/3/181/2003/.

Jenkin, M. E.: Modelling the formation and composition of secondary organic aerosol from $\alpha$ - and $\beta$-pinene ozonolysis using MCM v3, Atmos. Chem. Phys., 4, 1741-1757, doi:10.5194/acp4-1741-2004, 2004.

Jordan, C. E., Ziemann, P. J., Griffin, R. J., Lim, Y. B., Atkinson, R., and Arey, J.: Modeling SOA formation from $\mathrm{OH}$ reactions with $\mathrm{C}_{8}-\mathrm{C}_{17}$ n-alkanes, Atmos. Environ., 42, 8015-8026, 2008.

Isaacman, G., Chan, A. W. H., Nah, T., Worton, D. R., Ruehl, C. R., Wilson, K. R., and Goldstein, A. H.: Heterogeneous OH oxidation of motor oil particles causes selective depletion of branched and less cyclic hydrocarbons, Environ. Sci. Technol., 46, 1063210640, 2012.

Kirchstetter, T. W., Singer, B. C., Harley, R. A., Kendall, G. R., and Traverse, M.: Impact of California reformulated gasoline on motor vehicle emissions. 1. Mass emission rates, Environ. Sci Technol., 33, 318-328, 1999.

Kleinman, L. I., Springston, S. R., Daum, P. H., Lee, Y. N., Nunnermacker, L. J., Senum, G. I., Wang, J., Weinstein-Lloyd, J., Alexander, M. L., Hubbe, J., Ortega, J., Canagaratna, M. R., and Jayne, J.: The time evolution of aerosol composition over the Mexico City plateau, Atmos. Chem. Phys., 8, 1559-1575, 2008 ,

http://www.atmos-chem-phys.net/8/1559/2008/.Klotz, B., Barnes, I., and Imamura, T.: Product study of the gas-phase reactions of $\mathrm{O}_{3}, \mathrm{OH}$ and $\mathrm{NO}_{3}$ radicals with methyl vinyl ether, Phys. Chem. Chem. Phys., 6, 1725-1734, 2004.

Kroll, J. H., Smith, J. D., Che, D. L., Kessler, S. H.,Worsnop, D. R., and Wilson, K. R.: Measurement of fragmentation and functionalization pathways in the heterogeneous oxidation of oxidized organic aerosol, Phys. Chem. Chem. Phys., 11, 8005-8014, 2009.

Kroll, J. H., Donahue, N. M., Jimenez, J. L., Kessler, S. H., Canagaratna, M. R., Wilson, K. R., Altieri, K. E., Mazzoleni, L. R., Wozniak, A. S., Bluhm, H., Mysak, E. R., Smith, J. D., Charles, E. K., and Worsnop, D. R.: Carbon oxidation state as a metric for describing the chemistry of atmospheric organic aerosol, Nature Chem., 3, 133-139, 2011. 
Lambe, A. T., Onasch, T. B., Croasdale, D. R., Wright, J. P., Martin, A. T., Franklin, J. P., Massoli, P., Kroll, J. H., Canagaratna, M. R., Brune, W. H., Worsnop, D. R., and Davidovits, P.: Transitions from functionalization to fragmentation reactions of laboratory secondary organic aerosol (SOA) generated from the $\mathrm{OH}$ oxidation of alkanes precursors, Environ. Sci. Technol., 46, 54305437, 2012.

Lee, A. K. Y., Herckes, P., Leaitch, W. R., Macdonald, A. M., and Abbatt, J. P. D.: Aqueous OH oxidation of ambient organic aerosol and cloud water organics: Formation of highly oxidized products, Geophys. Res. Lett., 38, L11805, doi:10.1029/2011GL047439, 2011.

Lim, Y. B. and Ziemann, P. J.: Products and mechanism of secondary organic aerosol formation from reactions of n-alkanes with $\mathrm{OH}$ radicals in the presence of $\mathrm{NO}_{\mathrm{x}}$, Environ. Sci. Technol., 39, 9229-9236, 2005.

Lim, Y. B. and Ziemann, P. J.: Effects of molecular structure on aerosol yields from $\mathrm{OH}$ radical-initiated reactions of linear, branched, and cyclic alkanes in the presence of $\mathrm{NO}_{\mathrm{x}}$, Environ. Sci. Technol., 43, 2328-2334, 2009a.

Lim, Y. B. and Ziemann, P. J.: Chemistry of secondary organic aerosol formation from $\mathrm{OH}$ radical-initiated reactions of linear, branched, and cyclic alkanes in the presence of $\mathrm{NO}_{\mathrm{x}}$, Aero. Sci. Technol., 43, 604-619, 2009b.

Lim, Y. B. and Ziemann, P. J.: Kinetics of the heterogeneous conversion of 1,4-hydroxycarbonyls to cyclic hemiacetals and dihydrofurans on organic aerosol particles, Phys. Chem. Chem. Phys., 11, 8029-8039, 2009c.

Liu, S., Day, D. A., Shields, J. E., and Russell, L. M.: Ozone-driven daytime formation of secondary organic aerosol containing carboxylic acid groups and alkane groups, Atmos. Chem. Phys., 11, 8321-8341, doi:10.5194/acp-11-8321-2011, 2011.

Loza, C. L., Craven, J. S., Yee, L. D., Coggon, M. M., Schwantes, R. H., Shiraiwa, M., Zhang, X., Schilling, K. A., Ng, N. L., Canagaratna, M. R., Ziemann, P. J., Flagan, R. C., and Seinfeld, J. H.: Secondary organic aerosol yields of 12-carbon alkanes, Atmos. Chem. Phys. Discuss., 13, 20677-20727, doi:10.5194/acpd-1320677-2013, 2013.

MathWorks, MATLAB, 2002.

Martin, P., Tuazon, E. C., Aschmann, S. M., Arey, J., and Atkinson, R.: Formation and atmospheric reaction of 4,5-dihydro-2methylfuran, J. Phys. Chem. A, 106, 11492-11501, 2002.

Miracolo, M. A., Presto, A. A., Lambe, A. T., Hennigan, C. J., Donahue, N. M., Kroll, J. H., Worsnop, D. R., and Robinson, A. L.: Photooxidation of low-volatility organics found in motor vehicle emissions: production and chemical evolution of organic aerosol mass, Environ. Sci. Technol., 44, 1638-1643, 2010.

Miracolo, M. A., Hennigan, C. J., Ranjan, M., Nguyen, N. T., Gordon, T. D., Lipsky, E. M., Presto, A. A., Donahue, N. M., and Robinson, A. L.: Secondary aerosol formation from photochemical aging of aircraft exhaust in a smog chamber, Atmos. Chem. Phys., 11, 4135-4147, doi:10.5194/acp-11-4135-2011, 2011.

Ng, N. L., Canagaratna, M. R., Zhang, Q., Jimenez, J. L., Tian, J., Ulbrich, I. M., Kroll, J. H., Docherty, K. S., Chhabra, P. S., Bahreini, R., Murphy, S. M., Seinfeld, J. H., Hildebrandt, L., Donahue, N. M., DeCarlo, P. F., Lanz, V. A., Prévôt, A. S. H., Dinar, E., Rudich, Y., and Worsnop, D. R.: Organic aerosol components observed in Northern Hemispheric datasets from
Aerosol Mass Spectrometry, Atmos. Chem. Phys., 10, 46254641, doi:10.5194/acp-10-4625-2010, 2010.

Ng, N. L., Canagaratna, M. R., Jimenez, J. L., Chhabra, P. S., Seinfeld, J. H., and Worsnop, D. R.: Changes in organic aerosol composition with aging inferred from aerosol mass spectra, Atmos. Chem. Phys., 11, 6465-6474, doi:10.5194/acp-11-64652011, 2011.

Pankow, J. F. and Asher, W. E.: SIMPOL.1: a simple group contribution method for predicting vapor pressures and enthalpies of vaporization of multifunctional organic compounds, Atmos. Chem. Phys., 8, 2773-2796, doi:10.5194/acp-8-27732008, 2008.

Paulot, F., Crounse, J. D., Kjaergaard, H. G., Kurten, A., St. Clair, J. M., Seinfeld, J. H., and Wennberg, P. O.: Unexpected epoxide formation in the gas-phase photooxidation of isoprene, Science, 325, 730-733, 2009.

Presto, A. A., Miracolo, M. A., Kroll, J. H.; Worsnop, D. R., Robinson, A. L., and Donahue, N. M.: Intermediate-volatility organic compounds: a potential source of ambient oxidized organic aerosol, Environ. Sci. Technol. 43, 4744-4749, 2009.

Presto, A. A., Miracolo, M. A., Donahue, N. M., and Robinson, A. L.: Secondary organic aerosol formation from high- $\mathrm{NO}_{\mathrm{x}}$ photooxidation of low volatility precursors: n-alkanes, Environ. Sci. Technol. 44, 2029-2034, 2010.

Reisen, F., Aschmann, S. M., Atkinson, R., and Arey, J.: 1, 4Hydroxycarbonyl products of the $\mathrm{OH}$ radical initiated reactions of $\mathrm{C}_{5}-\mathrm{C}_{8}$ n-alkanes in the presence of NO, Environ. Sci. Technol., 39, 4447-4453, 2005.

Robinson, A. L., Donahue, N. M., Shrivastava, M. K., Weitkamp, E. A., Sage, A. M., Grieshop, A. P., Lane, T. E., Pierce, J. R., and Pandis, S. N.: Rethinking organic aerosols: semivolatile emissions and photochemical aging, Science, 315, 1259-1262, 2007.

Russell, L. M., Bahadur, R., and Ziemann, P. J.: Identifying organic aerosol soures by comparing functional group composition in chamber and atmospheric particles, Proc. Natl. Acad. Sci., 108, 3516-3521, 2011.

Sadezky, A., Chaimbault, P., Mellouki, A., Römpp, A., Winterhalter, R., Le Bras, G., and Moortgat, G. K.: Formation of secondary organic aerosol and oligomers from the ozonolysis of enol ethers, Atmos. Chem. Phys., 6, 5009-5024, doi:10.5194/acp-6-50092006, 2006.

Sander, S. P., Abbatt, J., Barker, J. R., Burkholder, J. B., Friedl, R. R., Golden, D. M., Huie, R. E., Kolb, C. E., J., K. M., Moortgat, G. K., Orkin, V. L., and Wine, P. H.: Chemical kinetics and photochemical data for use in atmospheric studies, Evaluation No. 17. JPL Publication 10-6, Jet Propulsion Laboratory, Pasadena, http://jpldataeval.jpl.nasa.gov, 2011.

Saunders, S. M., Jenkin, M. E., Derwent, R. G., and Pilling, M. J.: Protocol for the development of the Master Chemical Mechanism, MCM v3 (Part A): tropospheric degradation of nonaromatic volatile organic compounds, Atmos. Chem. Phys., 3, 161-180, doi:10.5194/acp-3-161-2003, 2003.

Schauer, J. J., Kleeman, M. J., Gass, G. R., and Simoneit, B. R. T.: Measurement of emissions from air pollution sources. 2 . $\mathrm{C}_{1}$ through $\mathrm{C}_{30}$ organic compounds from medium duty diesel trucks, Environ. Sci. Technol., 33, 1578-1587, 1999.

Schauer, J. J., Kleeman, M. J., Gass, G. R., and Simoneit, B. R. T.: Measurement of emissions from air pollution sources. 5. $\mathrm{C}_{1}-$ 
$\mathrm{C}_{32}$ organic compounds from gasoline-powered motor vehicles, Environ. Sci. Technol., 33, 1578-1587, 1999.

St. Clair, J. M., McCabe, D. C., Crounse, J. D., Steiner, U., and Wennberg, P. O.: Chemical ionization tandem mass spectrometer for the in situ measurement of methyl hydrogen peroxide, Rev. Sci. Instrum., 81, 094102, doi:10.1063/1.3480552, 2010.

Thiault, G., Thévenet, R., Mellouki, A., and Le Bras, G.: OH and $\mathrm{O}_{3}$ initiated oxidation of ethyl vinyl ether, Phys. Chem. Chem. Phys., 4, 613-619, 2002.

Tkacik, D. S., Presto, A. A., Donahue, N. M., Robinson, A. M.: Secondary organic aerosol formation from intermediate-volatility organic compounds: cyclic, linear, and branched alkanes, Environ., Sci., Technol., 46, 8773-8781, 2012.

Yee, L. D., Craven, J. S., Loza, C. L., Schilling, K. A., Ng, N. L., Canagaratna, M. R., Ziemann, P. J., Flagan, R. C., and Seinfeld, J. H.: Secondary organic aerosol formation from Low-NO photooxidation of dodecane: evolution of multi-generation gasphase chemistry and aerosol composition, J. Phys. Chem. A, 116, 6211-6230, 2012.
Zhang, X. and Seinfeld, J. H.: A functional group oxidation model (FGOM) for SOA formation and aging, Atmos. Chem. Phys., 13, 5907-5926, doi:10.5194/acp-13-5907-2013, 2013.

Zielinska, B., Sagebiel, J. C., Harshfield, G., Gertler, A. W., Pierson, W. R.: Volatile organic compounds up to $\mathrm{C}_{20}$ emitted from motor vehicles, measurement methods, Atmos. Environ., 30, 22692286, 1996.

Ziemann, P. J. and Atkinson, R.: Kinetics, products, and mechanisms of secondary organic aerosol formation, Chem. Soc. Rev., 41, 6582-6605, 2012. 